\title{
Preclinical Evidence for the Pharmacological Actions of Naringin: A Review
}

Authors

Affiliation
Saurabh Bharti, Neha Rani, Bhaskar Krishnamurthy, Dharamvir Singh Arya

Department of Pharmacology, All India Institute of Medical Sciences, New Delhi, India
Key words

- naringin

- flavonoid

- antioxidant

- anti-inflammatory

atherosclerosis

- diabetes mellitus

- neurological disorders

- cardiovascular disorders

- hepatoprotection

- nephroprotection

- bone diseases

- gastrointestinal diseases

- metabolic syndrome

- dentistry

- cancer

- allergy

- drug interaction

- pharmacokinetics received August 12, 2013

revised February 10, 2014

accepted March 10, 2014

\section{Bibliography}

DOI http://dx.doi.org/

10.1055/s-0034-1368351

Published online Apil 7, 2014

Planta Med 2014; 80: 437-451

(c) Georg Thieme Verlag KG

Stuttgart · New York .

ISSN 0032-0943

\section{Correspondence}

\section{Dr. D. S. Arya, Professor}

Department of Pharmacology

All India Institute of Medical

Sciences

Ansari Nagar

New Delhi 110029

India

Phone: + 911126594266

Fax: + 911126584121

dsarya16@hotmail.com

\section{Abstract}

$\nabla$

Naringin, chemically 4',5,7- trihydroxyflavanone-

7-rhamnoglucoside, is a major flavanone glycoside obtained from tomatoes, grapefruits, and many other citrus fruits. It has been experimentally documented to possess numerous biological properties such as antioxidant, anti-inflammatory, and antiapoptotic activities. In vitro and in vivo studies have further established the usefulness of naringin in various preclinical models of atherosclerosis, cardiovascular disorders, diabetes mellitus, neurodegenerative disorders, osteoporosis, and rheumatological disorders. Apart from this, naringin has also exerted chemopreventive and anticancer attributes in various models of oral, breast, colon, liver, lung, and ovarian cancer. This wide spectrum of biological expediency has been documented to be a result of either the upregulation of various cell survival proteins or the inhibition of inflammatory processes, or a combination of both. Due to the scarcity of human studies on naringin, this review focuses on the various established activities of naringin in in vitro and in vivo preclinical models, and its potential therapeutic applications using the available knowledge in the literature. Additionally, it also encompasses the pharmacokinetic properties of naringin and its inhibition of CYP isoenzymes, and the subsequent drug interactions. Moreover, further clinical research is evidently needed to provide significant insights into the mechanisms underlying the effects of naringin in humans.

\section{Abbreviations \\ $\nabla$ \\ ABTS: $\quad$ 2,2-azinobis(3-ethylbenzothiazoline- 6-sulfonic acid) diammonium salt \\ Akt: $\quad$ protein kinase $B$ \\ AMPK: AMP-activated protein kinase \\ AP: $\quad$ activator protein}

BDNF: brain-derived neurotrophic factor

BMP: bone morphogenetic protein

DMBA: 7,12-dimethylbenz[a]anthracene

DNFB: 2,4-dinitrofluorobenzene

DPP: dipeptidyl peptidase

DSS: dextran sodium sulphate

EGF: epidermal growth factor

eNOS: endothelial nitric oxide synthase

ER: estrogen receptor

ERK: extracellular signal-regulated kinase

FRAP: ferric reducing antioxidant power

GSK: glycogen synthase kinase

hDuox2: human dual oxidase 2

HMG-CoA: hydroxymethylglutaryl-coenzyme A

HUVECs: human umbilical vascular endothelial cells

IC: inhibitory concentration

ICAM-1: intercellular adhesion molecule 1

IFN: interferon

IKK: $\quad$ I $k$ B kinase

IL: interleukin

iNOS: inducible nitric oxide synthase

IRS-1: insulin receptor substrate-1

JNK: c-Jun N-terminal kinase

Kir: $\quad$ inward rectifying potassium channel

LPS: lipopolysaccharides

MAPK: $\quad$ p38 mitogen-activated protein kinase

MCP-1: monocyte chemotactic protein-1

MDR: multidrug-resistance protein

MIP-1 $\alpha$ : macrophage inflammatory protein-1alpha

MMP: matrix metalloproteinase

mTOR: mammalian target of rapamycin

NF- $k$ B: nuclear factor kappa-light-chain-enhancer of activated $B$ cells

NK: neurokinin

NNK: $\quad$ 4-(methylnitrosamino)-1-(3-pyridyl)1-butanone

nNOS: neuronal nitric oxide synthase

Nrf2: nuclear factor-erythroid 2-related factor-2 
OATP: $\quad$ organic anion transporting polypeptide

PAF: $\quad$ platelet activating factor

PARP: poly (ADP-ribose) polymerase

PGC1- $\alpha$ : peroxisome proliferator-activated receptor gamma coactivator

$\mathrm{PGE}_{2}$ : $\quad$ prostaglandin $\mathrm{E}_{2}$

PhIP: $\quad$ 2-amino-1-methyl-6-phenylimidazo[4,5-b]pyridine

PPAR: $\quad$ peroxisome proliferator-activated receptors

RANKL: receptor activator of nuclear factor kappa-B ligand

RANTES: regulated on activation, normal T cell expressed and secreted
Sirt1: $\quad$ silent mating-type information regulation 2 homolog-1

SPLA2: $\quad$ secretory phospholipase A2

STZ: $\quad$ streptozotocin

SULT: $\quad$ sulfotransferases

TBARS: thiobarbituric acid reactive substances

TNF- $\alpha$ : tumor necrosis factor-alpha

VCAM-1: vascular cell adhesion molecule-1

VEGF: vascular endothelial growth factor

\section{Introduction}

$\nabla$

Naringin was first discovered by De Vry in the flowers of grapefruit trees growing in Java in 1857, but he did not publish his findings at that time [1]. Extensive research on this "novel compound" was conducted in the years to come by De Vry and Hoffman, and, subsequently, Will [2]. The name naringin is probably derived from the Sanskrit term "narangi' meaning "orange" [2]. It is present in citrus and grape fruits, beans, cherries, cocoa, oregano, and tomatoes [3-8]. It is present in grapefruit juice up to concentrations of $800 \mathrm{mg} / \mathrm{L}$ [9]. The chemical structure of naringin was first elucidated in 1928 by Asahina and Inubuse [10] and is depicted in 0 Fig. 1. Naringin is a flavanone glycoside composed of naringenin, an aglycone and neohesperidose attached to the hydroxyl group at C-7 and tastes bitter due to its glucose moiety [11]. Nevertheless, it can be converted to 1,3-diphenylpropan-1one, a compound 300-1800 times sweeter than sugar with a menthol-like refreshing sweet taste when treated with potassium hydroxide or another strong base [12]. Depending up on the maturity of the fruit and the method of purification, naringin naturally occurs as a mixture of chiral isomers that markedly vary in proportion [13].

Naringin typically exemplifies the term "phytopharmaceutical", which commonly refers to products obtained from plants that are found to be useful in human disorders. Naringin being a very common dietary constituent would invariably be present in a lot of the dietary products consumed by humans. Thus, a human being would be exposed to naringin intake in some form or another. Literature is replete with various researches and reviews that focus on the numerous potential therapeutic effects of naringin. In fact, a wide spectrum of beneficial effects has been attributed to naringin including cardiovascular, hypolipidemic, antiatherosclerotic, antidiabetic, neuroprotective, hepatoprotective, and anticancer activities $[14,15]$. These articles highlight the fact that naringin possesses the potential to be employed as a therapeutic agent in a large number and variety of human ailments. At the same time, the occurrence of adverse reactions with allopathic medications might encourage physicians to explore safer alternatives in complementary medicine, thus prompting the development of naringin and related flavonoids for therapeutic purposes.

Moreover, the knowledge of pharmacokinetic properties and potential interactions of naringin with other drugs would assume paramount importance, as it would provide guidance for the measures that should be taken and precautions to be followed during consumption of naringin, which would also simultaneously apply to patients taking other medications and concomitantly consuming dietary constituents rich in naringin. Unfortunately, information on these parameters of naringin are limited and scattered in the literature. Hence, this review aims at sum-

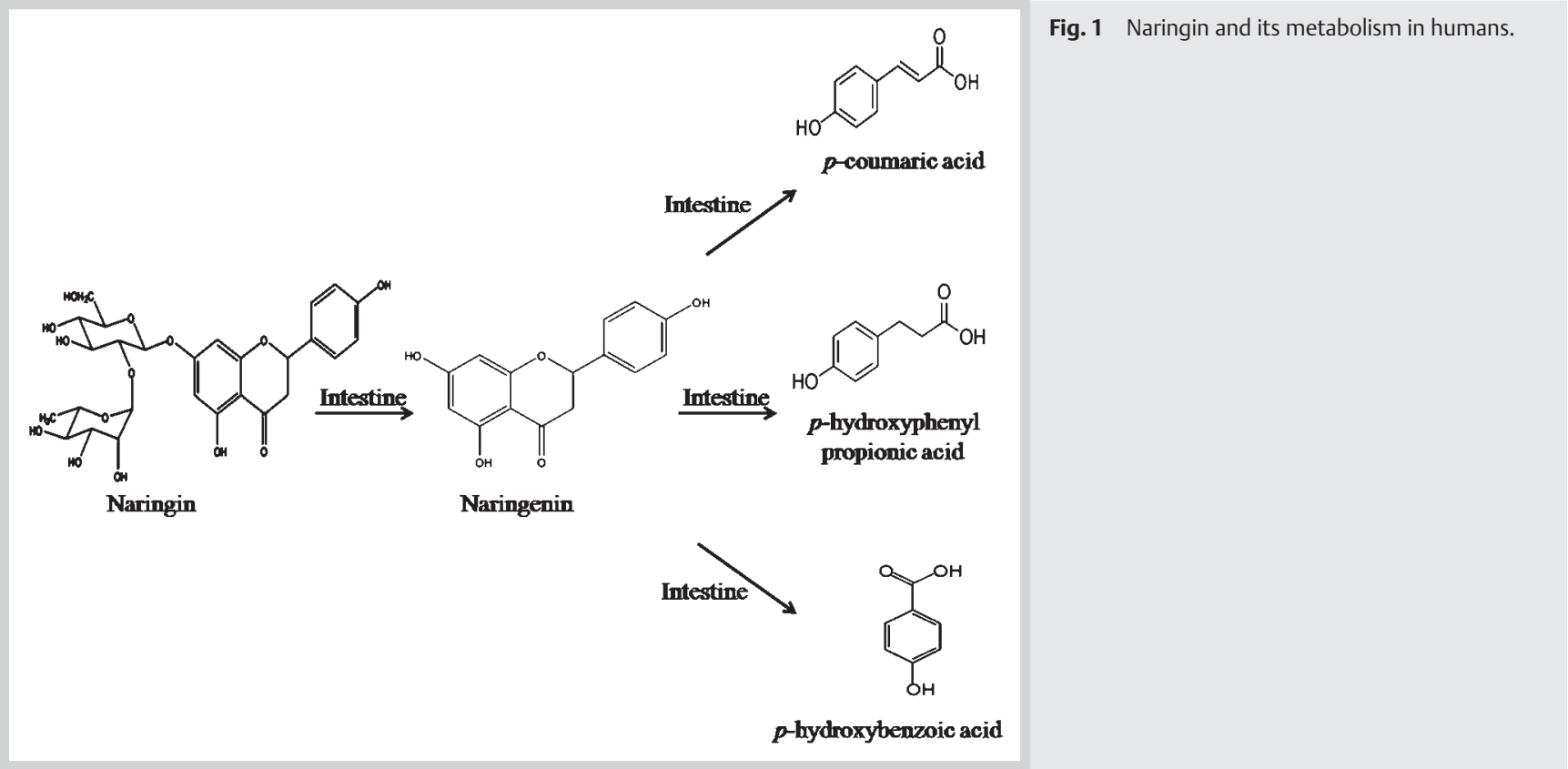


marizing the experimental work performed to date on biological actions, mechanisms of action, pharmacokinetic data, and clinically relevant drug interactions of naringin. To the best of our knowledge, this attempt is the first of its kind.

\section{Search Methodology}

Database searches using Google Scholar, Pubmed, and Science Direct were conducted until 15th December 2013 to include up-todate documented information in the present review article. The search was limited to English language papers. For data mining, the following MESH words were used in the databases mentioned above: naringin allergies, naringin Alzheimer's, naringin anti-inflammatory, naringin antioxidant, naringin anxiety, naringin apoptosis, naringin arthritis, naringin atherosclerosis, naringin bioavailability, naringin bone, naringin brain, naringin cancer, naringin cardioprotection, naringin cholesterol, naringin chromatography, naringin cough, naringin CYP, naringin dentistry, naringin dermatology, naringin diabetes, naringin drug interaction, naringin epilepsy, naringin gastrointestinal, naringin heart, naringin hepatoprotection, naringin hyperglycemia, naringin hyperlipidemia, naringin hypertension, naringin in vitro, naringin in vivo, naringin infection, naringin insulin, naringin kidney, naringin liver, naringin lungs, naringin malignancies, naringin metabolic syndrome, naringin nephroprotection, naringin neuroprotection, naringin obesity, naringin osteoporosis, naringin pain, naringin pharmacokinetics, naringin platelet, naringin prokinetic, naringin pulmonary system, naringin radiation, naringin radioprotection, naringin skin, naringin stroke, naringin toxicity, naringin transporter, naringin tumor, naringin ulcer, and naringin ulcerative colitis.

In almost all cases, the original articles were obtained and the relevant data was extracted.

\section{Pharmacokinetics}

$\nabla$

Extensive studies to elucidate the pharmacokinetic properties of naringin have been performed on rats [16-20], rabbits [21], dogs [22,23], and humans [24-26].

\section{Absorption}

Naringin, upon oral administration to rats, results in several metabolites like naringenin, naringenin glucuronide, and naringenin sulphate in the blood and urine [16-20]. The hydrolysis of naringin to naringenin is catalyzed by enzymes such as $\alpha$-rhamnosidases and $\beta$-glucosidases [20,27]. Additionally, naringin is also transformed by the intestinal microflora into many kinds of phenolic acids due to ring fission [27-29]. 4-Hydroxybenzoic acid, 2,4,6-trihydroxybenzoic acid, phloroglucinol, 4-hydroxyphenylpropionic acid, and 4-hydroxyphenylacetic acid have been identified as the major metabolites of naringin [22]. Besides, naringenin was incubated with rat liver microsomes and produced three metabolites (two naringenin hydroxylates and 5,7-dihydroxychromone) [30]. Tsai and Tsai demonstrated that the portal and lymphatic absorptions for naringin were about 95 and 5\%, respectively [18]. Naringin and naringenin are both detectable in plasma about five hours after oral administration [16,31].

\section{Distribution}

Zou and colleagues have demonstrated that naringin and its metabolites, being highly lipophilic, are distributed to almost all the body organs with the highest concentrations being observed in the stomach and the lowest in the brain due to reduced blood brain barrier permeability. Naringin is concentrated in the liver and bile by the processes of active transport $[32,33]$.

\section{Metabolism}

Naringin undergoes extensive phase I and phase II metabolism in the liver, as depicted in $\bigcirc$ Fig. 1. Liu and colleagues have identified a total of 23 metabolites of naringin after oral administration to rats $(42 \mathrm{mg} / \mathrm{kg}$ ) and dogs $(12.4 \mathrm{mg} / \mathrm{kg}$ ). They identified 4-hydroxyphenylpropionic acid (37\% in dogs and $16 \%$ in rats) as a major metabolite of naringin [22].

\section{Elimination}

Elimination of naringin occurs both by the kidneys into urine and by the liver into bile by partly undergoing bacterial ring cleavage (of the C-ring), and subsequently the three carbon bridges to the dihydrochalcone moiety. The excretion in urine varies from 5 to $57 \%$ of the consumption according to an observation by Fuhr and Kummert [34]. Sixty percent of an administered dose was recovered from the urine and feces of dogs and $21 \%$ in rats in the form of metabolites within $36 \mathrm{~h}$ after administration by Liu and coworkers [22]. However, at $48 \mathrm{~h}$ post-dose, $1 \%$ of administered naringin was recovered from the urine of rats and $8 \%$ in dogs as free naringin and naringenin, which was similar to that in humans (about 5\%) [22,24-26]. Ishii and coworkers studied the elimination of naringin in a single healthy volunteer who received $500 \mathrm{mg}$ of naringin. They observed that the peak urinary level of naringin $(\sim 64 \mu \mathrm{g})$ was attained at around $4 \mathrm{~h}$, naringenin $(\sim 850 \mu \mathrm{g})$ at around $24 \mathrm{~h}$, and naringenin glucuronides $(\sim 4 \mathrm{mg})$ at around $10 \mathrm{~h} \mathrm{[24].}$

\section{Drug interactions}

$\nabla$

As traditional medicines become increasingly popular globally, the significant potential for interaction between traditional medicines and allopathic medicines tends to hog the limelight. Numerous studies have shown that naringin interferes with the activities of transporters and enzymatic proteins in the intestines and, hence, with the absorption and breakdown of certain drugs, resulting in altered blood levels of these drugs. Naringin is a potent inhibitor of transporter proteins such as OATP isoforms as well MDR and SULT. This leads to decreased absorption and, hence, bioavailability of drugs such as pitavastatin [35] via inhibition of OATP1A5 and MDR-1, imatinib via inhibition of OATP1A2 [36], and $\beta_{2}$ agonists via SULT1 and SULT3 [37]. Naringin also inhibits the sulfation of various drugs such as paracetamol and minoxidil via P-form phenolsulfo-transferase inhibition and, thus, interferes with their metabolism, leading to increased plasma levels in these drugs [38]. Contrarily, naringin enhances the absorption of colchicine through p-glycoprotein modulation [39]. Naringin also inhibits various CYP isoenzymes, thus increasing the bioavailability of calcium channel blockers such as verapamil [40] via CYP3A4 and paclitaxel via CYP3A1/2 inhibition [41]. Nevertheless, naringin has also been shown to have no effect on the pharmacokinetics of drugs such as doxorubicin [42] and caffeine [43]. 
In another investigation, naringin has been shown to mediate the chemosensitizing effect via reducing anticancer drug-induced pglycoprotein expression, a membrane-associated drug efflux pump whose increased expression results in the resistance to anticancer drugs such as doxorubicin [44]. Moreover, naringin also inhibits the activation of carcinogens by CYP isoenzymes, thus suggesting a role in the prevention of carcinogenesis [45].

\section{Effects of Naringin}

$\nabla$

\section{Antioxidant effect}

In vitro: In the earliest of reports, naringin was shown to possess strong superoxide scavenging activity ( IC $_{50}$ of $192.0 \pm 6.7 \mu \mathrm{M}$ ) [46] and xanthine oxidase inhibitory activity (200-400 $\mu \mathrm{M})$ [47]. Studies conducted on erythrocytes exposed to phenazine methosulfate and diethyldithiocarbamate have provided strong evidence regarding the ability of naringin $(0-500 \mu \mathrm{M})$ to quench ROS, decrease the oxygen-free radical-stimulated $\mathrm{K}^{+}$permeability, and inhibit lipid peroxidation [48]. This ability to scavenge free radicals has also contributed to the inhibition of the nitriteinduced oxidation of hemoglobin to methemoglobin in erythrocytes by naringin $(0.02-2.0 \mathrm{mM})$ [49] and the reduction of glucose-6-phosphate dehydrogenase inactivation by low-frequency ultrasound cavitation $(0.01-50 \mu \mathrm{M})$ [50]. Naringin $(1-100 \mu \mathrm{M})$ was also shown to reverse the ROS-mediated apoptosis via caspase-3 activation in human polymorphonuclear neutrophils [51]. Jagetia and coworkers have demonstrated that naringin (0.5-5 mmol/L) significantly suppressed iron-induced lipid peroxidation, protein oxidation, and DNA damage [52]. As an extension of this work, the same group also revealed that naringin $(50 \mathrm{nM})$ could inhibit iron-induced oxidative stress in iron overloaded isolated mouse liver mitochondria [53].

The antioxidant potential of naringin could prove to be of therapeutic importance in diabetes mellitus and neurodegenerative disorders. Naringin $(30 \mu \mathrm{M})$ has reduced high glucose-induced upregulation of ICAM-1 via its antioxidant effect, thus suggesting a potential ameliorating effect on the macrovascular complications of diabetes mellitus [54]. Naringin $(80 \mu \mathrm{mol} / \mathrm{L})$ has also been shown to inhibit the ROS-activated MAPK pathway in high glucose-induced injury in $\mathrm{H} 9 \mathrm{c} 2$ cardiac cells [55]. In PC12 neuronal cells, naringin (3.125-25 $\mu \mathrm{M}$ ) can significantly inhibit $\mathrm{H}_{2} \mathrm{O}_{2}$-induced cytotoxicity via attenuating caspase-3 and MMP-9 expression, and bolstering the antioxidant defense system, thus ameliorating neurodegeneration [56]. Naringin $(80 \mathrm{mg} / \mathrm{kg}$ ) can also significantly reduce 3-nitropropionic acid-induced neurodegeneration in rats via oxidative stress inhibition and Nrf2 activation [57] as well as inhibition of apoptotic markers (Bax and Bad) [58]. Naringin ( $1 \mathrm{mM}$ and $200 \mathrm{mM}$, respectively) has been shown to inhibit $\mathrm{H}_{2} \mathrm{O}_{2}$ and cytosine arabinoside-induced cytotoxicity and apoptosis in mouse leukemia P388 cells via augmenting the antioxidant enzyme activities $[59,60]$. Naringin has shown significant protection against DNA damage induced by UV-A radiation in mouse embryo fibroblast C3H10T1/2 cells at doses of 10 and $23 \mu \mathrm{M}$ [61] and gamma-irradiated human white blood cells at a dose of $50 \mu \mathrm{M}$, which might be due to its ability to quench $\mathrm{O}_{2}$ [62]. Naringin (1-2 $\mu \mathrm{g} / \mathrm{ml}$ and $1 \mathrm{mM}$, respectively) significantly attenuated the cadmium and bleomycin-induced genomic damage in human lymphocytes [63] and V79 cells [64]. Similarly, it also reduced the benz[a]pyrene phototoxicity (an air pollutant responsible for mutagenicity and carcinogenicity) in Balb/c 3T3 cells at doses ranging from 0.1-1.0 mM [65].
In a comparative study, naringenin was found to be more potent than naringin in scavenging superoxide (with 4-nitroblue tetrazolium chloride, $\mathrm{IC}_{50}$ of $94.7 \pm 0.9$ vs. $169 \pm 2.9$ and with xanthine oxidase, $\mathrm{IC}_{50}$ of $4.4 \pm 0.2$ vs. $230 \pm 4.6$ ) and hydroxyl radicals (with EDTA, $I_{50}$ of $1.06 \pm 0.004$ vs. $1.36 \pm 0.03$ and without EDTA, $1.55 \pm 0.1$ vs. $2.66 \pm 0.07)$. Moreover, in the same study, an ABTS assay showed that naringenin $(7.9 \pm 0.2 \mu \mathrm{mol} / \mathrm{L})$ exhibited a higher capacity to inhibit $50 \%$ of ABTS radical cation generation than naringin $(27.1 \pm 0.4 \mu \mathrm{mol} / \mathrm{L})$ and, at the same dose $(0.1-0.5 \mathrm{mg} /$ $\mathrm{mL}$ ), has significantly higher antioxidant efficiency as exemplified by the FRAP assay [66]. Additionally, naringin-Cu (II) complex 1 also exhibited higher antioxidant, anti-inflammatory, and tumor cell cytotoxic effects as compared with naringin alone [67]. In vivo: Naringin ( $3 \%$ fed to flies in culture medium) has been shown to inhibit the protein hDuox2, a member of the NADPH oxidase family, in a GMR-GAL4/UAS-hDuox2 fly line screening model, thereby implicating a strong antioxidant potential through inhibition of ROS [68]. The same antioxidant potential of dietary naringin $(1.5-3.0 \mathrm{~g} / \mathrm{kg}$ ) was responsible for decreased serum triacylglycerol levels in fish oil supplemented fattening lambs [69]. In fact, in a comparative study, dietary naringin $(0.5 \mathrm{~g} / \mathrm{kg})$ exerted an antioxidant effect comparable to that of probucol $(0.5 \mathrm{~g} / \mathrm{kg})$ and lovastatin $(0.3 \mathrm{~g} / \mathrm{kg})$ administered for the same duration [70,71].

Naringin administered at a dose of $400 \mathrm{mg} / \mathrm{kg}$ has been reported to ameliorate renal ischemia-reperfusion injury through free radical scavenging and antioxidant properties [72]. Naringin (5 and $10 \mathrm{mg} / \mathrm{kg}$ ) has also shown protective effects in testicular ischemia-reperfusion-induced oxidative stress in rats [73].

In rats, naringin at a dose of $20-80 \mathrm{mg} / \mathrm{kg}$ has been shown to exert a protective effect against nickel sulphate-induced nephrotoxicity and hepatotoxicity via attenuating the injury markers and lipid peroxidation, as well as increasing the antioxidant status $[74,75]$. Likewise, naringin at a dose of $100-400 \mathrm{mg} / \mathrm{kg}$ has also been shown to ameliorate ferric-nitrilotriacetate and glycerolinduced nephrotoxicity in rats via normalizing plasma creatinine, blood urea nitrogen, urea clearance, and bolstering renal antioxidant levels $[76,77]$. Naringin $(50-500 \mathrm{mg} / \mathrm{kg}$ ) also prevented the cardiomyocyte and hepatocyte DNA damage produced by daunorubicin in mice, probably due to its strong capacity to trap free radicals [78]. It (5-50 $\mathrm{mg} / \mathrm{kg}$ ) has also been shown to have a protective role in the abatement of lomefloxacin-induced genomic instability in mice, most likely due to its antioxidant effects [79]. Naringin ( $50 \mathrm{mg} / \mathrm{kg}$ ) has been shown to protect against hyperglycemia-mediated oxidative stress and proinflammatory cytokine production in high-fat fed/streptozotocin-induced type 2 diabetic rats [80]. Moreover, owing to its antioxidant potential, naringin (25-50 mg/kg) substantially prevented diabetes-induced chromosomal instability in rats [81].

Naringin $(2 \mathrm{mg} / \mathrm{kg}$ ) shielded mouse bone marrow, intestines, and the liver against radiation-induced damage by reducing the lipid peroxidation and elevating the antioxidant status [82,83]. Similarly, naringin at a dose of $100 \mathrm{mg} / \mathrm{kg}$ protected the mice from the lethal effects of whole-body irradiation [84]. Cumulatively, these studies have established the usefulness of naringin in ROSassociated diseases.

\section{Anti-inflammatory effect}

In vitro: Naringin ( $1 \mathrm{mM})$ suppressed LPS-induced synthesis of NO, iNOS, COX-2, TNF- $\alpha$, IL-6 production, and NF- $k$ B activation in RAW 264.7 macrophages [85]. In the same model, naringin (50-200 $\mu \mathrm{M})$ has been shown to mediate its anti-inflammatory 
effect by inhibiting IL-8, MCP-1, and MIP- $1 \alpha$ secretion and mRNA expression, and by inhibiting the phosphorylation of ERK1/2, JNK, and p38 MAPK, probably through blocking the activation of the NF- $k B$ and MAPK signaling pathways [86]. It $(0.25$ and $0.5 \mathrm{mmol} / \mathrm{L}$ ) also significantly inhibited the TNF- $\alpha / \mathrm{IFN}-\gamma$-induced RANTES expression in human HaCaT cells via the NF- $k$ B-dependent signaling pathway [87]. It significantly attenuated enzymatic activity of sPLA2 and its associated pharmacological effects such as myonecrosis, platelet aggregation, and cytotoxicity [88]. It $(10-50 \mu \mathrm{g} / \mathrm{ml})$ also interfered with monocyte adhesion and subsequently reduced high-glucose-induced vascular inflammation in HUVECs [89]. In a study by Lee and Kim, naringin was shown to inhibit both COX-1 and COX-2 ( IC $_{50}>100$ and 60.02, respectively) and also LPS-stimulated nitric oxide production $\left(\mathrm{IC}_{50}\right.$ $>100$ ), thereby implicating its usefulness in rheumatoid arthritis and other inflammatory diseases [90]. In addition, a naringinleucine $(\mathrm{N}-\mathrm{Leu})$ combination $(15-150 \mu \mathrm{M})$ reduced the hyperinflammatory status in cystic fibrosis cell lines via inhibiting the expression levels of IKK $\alpha$, IKK $\beta$, NF- $\kappa$ B, and phosphorylation of ERK1/2 kinase [91].

In vivo: Modern scientific researches, as described further, have demonstrated that naringin exerts an anti-inflammatory effect in numerous chronic inflammatory diseases. Naringin (10$60 \mathrm{mg} / \mathrm{kg}$ and $0.3-3 \mathrm{mg} / \mathrm{mouse}$, respectively) has shown protection against LPS-induced endotoxic shock in male ddY mice via inhibition of TNF- $\alpha$ release [85] and blocked the lethal shock in D-galactosamine-sensitized C57BL/10ScSn mice [92]. It (15$60 \mathrm{mg} / \mathrm{kg}$ ) also significantly ameliorated LPS-induced acute lung injury in mice via suppression of myeloperoxidase, iNOS activity, TNF- $\alpha$ secretion, and NF- $k$ B activation [93]. In rats exposed to endotoxin, naringin $(0.4-40 \mu \mathrm{g} / \mathrm{kg})$ prevented the occurrence of uveitis via inhibition of $\mathrm{PGE}_{2}$ and NO [94]. Pretreatment with naringin $(20-80 \mathrm{mg} / \mathrm{kg})$ substantially reduced chronic pulmonary neutrophilic inflammation in cigarette smoke-exposed rats [95]. In a guinea pig model of chronic bronchitis induced by cigarette smoke, naringin $(9.2-36.8 \mathrm{mg} / \mathrm{kg}$ ) attenuated airway hyperresponsiveness and airway inflammation along with a decrease in coughing [96]. Moreover, in the same model, naringin $(18.4 \mathrm{mg} / \mathrm{kg}$ ) was shown to be effective in inhibiting both airway neurogenic inflammation and coughs through a mechanism involving a significant reduction in substance P content and NK-1 receptor expression [97]. Naringin (30 mg/kg) has also shown significantly potent anti-inflammatory potential in the rat air pouch model of inflammation [98]. In a DSS-induced ulcerative colitis mouse model, naringin $(15.8 \mathrm{mg} / \mathrm{kg})$ inhibited the production of nitrates and nitrites (indicators of the inflammatory process), and reduced intestinal edema, suggesting its potential therapeutic role in the treatment of inflammatory bowel disease [99]. A collaborative research from our laboratory has shown that naringin $(20,40$, and $80 \mathrm{mg} / \mathrm{kg})$ significantly protects against the kainic acid-induced status epilepticus and cognitive impairment in rats via anti-inflammatory and antioxidant pathways [100]. Collectively, these preclinical studies have identified a diverse range of biological targets and intricate mechanisms of action that characterize naringin as an extremely potent anti-inflammatory molecule.

\section{Therapeutic potential of naringin}

Naringin has been shown to exert potential therapeutic benefits by modulating various protein expressions in a wide gamut of human disorders as summarized in 0 Tables $\mathbf{1}$ and $\mathbf{2}$

\section{Atherosclerosis}

In vitro: Studies have shown that naringin prevents in vitro LDL oxidation and therefore could potentially retard the progression of atherosclerosis [101]. Another mechanism of naringin $(25 \mu \mathrm{M})$ that has been elucidated is the inhibition of the transfer of an acetyl group from PAF to lysophospholipids that prevents the activation of endothelial cells and, hence, retards the process incriminated in the development of an atherosclerotic plaque [102]. An initiating step in the pathophysiology of atherosclerosis is the proliferation of vascular smooth muscle cells that is inhibited by naringin by multiple mechanisms, namely, induction of p21WAF1-mediated G1-phase cell cycle arrest in vascular smooth muscle cells via activation of the Ras/Raf/ERK signaling pathway at a concentration of $0-150 \mu \mathrm{M}$ [103] and repression of the PI3K/AkT/mTOR/p70S6K pathway and MMP-9 expression through the transcription factors NF- $k$ B and AP- 1 in TNF- $\alpha$-induced vascular smooth muscle cells at a concentration of 10 $25 \mu \mathrm{M}$ [104].

In vivo: The hypocholesterolemic potential of naringin suggests a utility in therapy of atherosclerosis, which has been further substantiated by various studies, as described below. Naringin has been shown to inhibit hepatic HMG-CoA reductase (a rate limiting enzyme of the cholesterol biosynthetic pathway) and acyl CoA:cholesterol acyltransferase (a cholesterol esterifying enzyme) when administered to high-cholesterol fed rats at a dose of $1 \mathrm{~g} / \mathrm{kg}$ [105]. The inhibition of HMG-CoA reductase was also demonstrated by Lee and coworkers in high-cholesterol fed rabbits, administered dietary naringin $1 \mathrm{~g} / \mathrm{kg}$, along with that of other proteins involved in the adhesion of leukocytes to the endothelium such as VCAM-1 and MCP-1 [106]. Naringin $(0.5 \mathrm{~g} / \mathrm{kg})$ has also been shown to decrease the expression of ICAM-1 in endothelial cells, fatty streak formation, and neointimal macrophage infiltration in hypercholesterolemic rabbits [107], and also lower plasma cholesterol levels [108]. Similar results were also reported by Kim and coworkers in cholesterol fed LDL-receptor knockout mice when dietary naringin was administered at a dose of $0.2 \mathrm{~g} / \mathrm{kg}$ [109]. Naringin $(0.2 \mathrm{~g} / \mathrm{kg})$ reduced the hepatic synthesis of cholesterol and, subsequently, the plasma lipid levels in Sprague-Dawley rats after 6 weeks of administration [110]. Naringin $(0.2 \mathrm{~g} / \mathrm{kg})$ also prevents the adhesion of immune cells, their infiltration in the intima of the vascular wall, and, subsequently, smooth muscle cell proliferation as observed in diet-induced hypercholesterolemic mice [111]. Beneficial effects were also observed in humans by Jung and coworkers, in whom dietary naringin $(0.4 \mathrm{~g} / \mathrm{kg})$ reduced plasma LDL-cholesterol levels along with apolipoprotein B levels [112]. Nevertheless, contrasting results have also been obtained as naringin $(0.5 \mathrm{~g} / \mathrm{kg})$ did not show any affect on serum total cholesterol and LDL-C concentrations in moderately hypercholesterolemic men and women [113].

\section{Cardiovascular disorders}

In vitro: Naringin $(0.1-0.3 \mathrm{mM})$ promoted relaxation of the isolated rat thoracic aortae in response to phenylephrine (a vasoconstrictor), the mechanism for which it was postulated to be an inhibition of $\mathrm{Ca}^{2+}$ influx and for the release of calcium from intracellular stores, suggesting a vasorelaxant effect [114]. This effect was further supported by Saponara and associates in endothelium-denuded rat aortic rings administered naringin at a concentration of $1-100 \mu \mathrm{M}$ [115]. Furthermore, the $\mathrm{K}^{+}$influx can also be activated by naringin $(100 \mu \mathrm{M})$ through a direct activation of the inward rectifying potassium channels [116]. Naringin $(5 \mu \mathrm{M})$ has also been shown to inhibit high-glucose-induced apoptosis in 


\begin{tabular}{|c|c|c|}
\hline System & Disorders & Reference \\
\hline \multirow{3}{*}{$\begin{array}{l}\text { Chemical/radiation- } \\
\text { induced damage }\end{array}$} & Radioprotection & {$[62]$} \\
\hline & Hepatotoxicity & [75] \\
\hline & Nephrotoxicity & [76], [77] \\
\hline Pulmonary system & Cough and bronchitis & [96], [97] \\
\hline \multirow[t]{4}{*}{ Cardiovascular } & Atherosclerosis and other thrombotic disorders & {$[106],[107]$} \\
\hline & Hypertension & {$[118]$} \\
\hline & Drug-induced cardiotoxicity & {$[119-122]$} \\
\hline & Myocardial infarction & [123] \\
\hline \multirow[t]{5}{*}{ Metabolic } & Type 2 diabetes & {$[126],[127]$} \\
\hline & Metabolic syndrome & [129] \\
\hline & Obesity & [131] \\
\hline & Diabetes neuropathy & [132] \\
\hline & Hyperlipidemia, insulin resistance, and hepatic steatosis & [134] \\
\hline \multirow[t]{10}{*}{ Neurological } & Epilepsy & {$[100]$} \\
\hline & Parkinson's disease & [135] \\
\hline & Alzheimer's disease & [136] \\
\hline & Memory enhancing & [137] \\
\hline & Stroke & [138] \\
\hline & Spinal cord injury & [139] \\
\hline & Cognitive dysfunction & {$[140],[141]$} \\
\hline & Huntington's disease & [142] \\
\hline & Depression & [143] \\
\hline & Anxiety & [144] \\
\hline \multirow[t]{9}{*}{ Cancers } & Breast cancer & [155] \\
\hline & Colon cancer & [160] \\
\hline & Cancer cervix & [162] \\
\hline & Bladder cancer & [163] \\
\hline & Lung cancer & [164], [165] \\
\hline & Liver cancer & [166] \\
\hline & Oral cavity cancers & [167] \\
\hline & Skin cancer & [168] \\
\hline & Sarcoma & [169], [170] \\
\hline \multirow[t]{2}{*}{ Bone diseases } & Osteoporosis & [186] \\
\hline & Rheumatoid arthritis & [187] \\
\hline Dental diseases & Dental caries & [191], [192] \\
\hline \multirow[t]{3}{*}{ Infections } & Salmonellosis & [196] \\
\hline & Filariasis & [197] \\
\hline & Dengue & [198] \\
\hline \multirow[t]{2}{*}{ Ocular diseases } & Uveitis & [94] \\
\hline & Cataract & [133] \\
\hline \multirow[t]{4}{*}{ Miscellaneous } & Ulcerative colitis & [99] \\
\hline & Contact dermatitis & [194] \\
\hline & Allergic rhinitis & [202] \\
\hline & Gastric ulcer & [203], [204] \\
\hline
\end{tabular}

Table 1 Various disorders in which naringin has been documented to be effective.
H9c2 cardiomyocyte cells through attenuation of mitochondrial dysfunction and modulation of the p38 signaling pathway [117]. In vivo: Naringin $(0.25-1.0 \mathrm{~g} / \mathrm{kg}$ ) augmented nitric oxide bioavailability, which contributed substantially to the amelioration of hypertension and cerebral thrombosis in stroke-prone, spontaneously hypertensive rats [118]. The cardioprotective effects of naringin can be explained at the molecular level, whereby naringin (10-40 $\mathrm{mg} / \mathrm{kg}$ ) has exerted protective effects against isoproterenol-induced myocardial damage by significantly increasing the activity of $\mathrm{Na}^{+}-\mathrm{K}^{+}$-ATPase, while reducing those of $\mathrm{Ca}^{2+}$ and $\mathrm{Mg}^{2+}$ ATPases, as evidenced by an improvement in the electrocardiographic patterns and cardiac injury markers [119-122]. Moreover, a study from our lab has also demonstrated that naringin $(20-80 \mathrm{mg} / \mathrm{kg}$ ) significantly decreased the infarct size in myocardial ischemia-reperfusion injury in rats through regulation of heat shock proteins 27 and 70, p-Akt/p-eNOS, and MAPKs [123].

\section{Diabetes mellitus}

In vitro: Naringin $(10 \mathrm{mM})$ has shown a greater inhibition of DPP-IV in comparison to an equivalent concentration of sitagliptin, with higher insulin secretion and glucose disposal along with the protective effects on the pancreatic islets, as reported by Parmar and coworkers [124]. Nevertheless, Purushotham and coworkers have observed that naringin $(100 \mu \mathrm{M})$ did not suppress hepatic glucose production in Fao hepatoma cells [125].

In vivo: Naringin $(0.2 \mathrm{~g} / \mathrm{kg})$ has been shown to prevent the progression of hyperglycemia in $\mathrm{C} 57 \mathrm{BL} / \mathrm{KsJ}-\mathrm{db} / \mathrm{db}$ mice via an increase in hepatic glycolysis and glycogen concentration, and lowering of hepatic gluconeogenesis [126]. Moreover, in another investigation by the same group and using the same model, it $(0.2 \mathrm{~g} / \mathrm{kg})$ also led to a reduction in hyperlipidemia and hyperglycemia [127]. More recently, naringin $(1 \mathrm{~g} / \mathrm{kg})$ has also been shown to mitigate the obesity-related inflammatory state in cats [128], as well as the metabolic syndrome in C57BL/6 mice (at a dose of $0.2 \mathrm{~g} / \mathrm{kg}$ ) fed a high-fat diet, owing to the AMPK stimula- 
Table 2 The expressions and activities of proteins modulated by naringin.

\begin{tabular}{|c|c|c|c|}
\hline Naringin decreases & Reference & Naringin increases & Reference \\
\hline OATP1A2, MRP-1, and MDR- 1 activity & [35] & Nrf2 expression & [57] \\
\hline SULT1A3 activity & [37] & I $\kappa \mathrm{B}-\alpha$ expression & [86] \\
\hline CYP3A4 and CYP3A1/2 levels & {$[40],[41]$} & $\mathrm{K}^{+}$influx & [116] \\
\hline P-gp expression & {$[44]$} & $\mathrm{Na}^{+} / \mathrm{K}^{+}$ATPase & {$[120]$} \\
\hline Xanthine oxidase activity & {$[47]$} & $\begin{array}{l}\beta \text {-catenin and p-eNOS expression, and NO, GSH, } \\
\text { SOD, GSH-Px, catalase, and LDH activities }\end{array}$ & [123] \\
\hline ICAM-1 expression & [54] & Glucokinase activity & [127] \\
\hline Bax and Bad expression & {$[58]$} & AMPK levels & [129] \\
\hline hDuox2 activity & {$[68]$} & $\begin{array}{l}\text { HDL-C and adiponectin levels, and PPAR- } \gamma, \text { HSP-27, } \\
\text { HSP-72, and phosphorylated-IRS- } 1 \text { expression }\end{array}$ & [134] \\
\hline iNOS, TNF- $\alpha$, IL-6, and COX-2 mRNA expression & [85] & SEK1 protein expression & [152] \\
\hline $\begin{array}{l}\text { IL-8 mRNA, MIP- } 1 \alpha \text { mRNA, MCP mRNA, p38MAPK, } \\
\text { p-p38MAPK, JNK, p-JNK, ERK, and p-ERK expression }\end{array}$ & [86] & DR-5 level & [162] \\
\hline sPLA2 activity & {$[88]$} & Ras/Raf/ERK expression & [163] \\
\hline NF-kB expression & [93] & IKK activity & [165] \\
\hline $\mathrm{PGE}_{2}$ level & [94] & ER- $\alpha$ protein expression & [173] \\
\hline Substance P content and NK-1 expression & [97] & PI3K/Akt, c-Fos/c-Jun, and BMP-2 expression & [175] \\
\hline MMP-9 and mTOR expression & [104] & $\begin{array}{l}\text { Alkaline phosphatase activity and COLI, OCN, } \\
\text { Runx2, and osteocalcin expression }\end{array}$ & [176], [177] \\
\hline ACAT activity & [108] & Sox9 level & [188] \\
\hline HMG-CoA reductase activity & [110] & & \\
\hline E-selectin & [111] & & \\
\hline LDL-cholesterol and apolipoprotein B levels & {$[112]$} & & \\
\hline $\mathrm{Ca}^{+2}$-ATPase and $\mathrm{Mg}^{+2}$-ATPase activity & {$[120]$} & & \\
\hline Cathepsin $\mathrm{B}$, cathepsin $\mathrm{D}$, and $\beta$-glucuronidase activity & {$[121]$} & & \\
\hline $\begin{array}{l}\text { Myocardial TBARS, serum CK-MB level, and nitrotyrosine } \\
\text { expression }\end{array}$ & [123] & & \\
\hline DPP-IV activity & [124] & & \\
\hline $\begin{array}{l}\text { Phosphoenolpyruvate carboxykinase and } \\
\text { glucose 6-phosphatase activity }\end{array}$ & {$[127]$} & & \\
\hline Aldose reductase activity & [133] & & \\
\hline $\begin{array}{l}\text { TC, LDL-C, and CRP levels, and SREBP-1c and LXR } \alpha \\
\text { expression }\end{array}$ & [134] & & \\
\hline Caspase 3 , caspase 9 , and PARP activity & [135] & & \\
\hline GSK-3 $\beta$ expression & [136] & & \\
\hline AChE activity and nNOS & {$[137]$} & & \\
\hline BDNF and VEGF expression & [139] & & \\
\hline CyclinD1/CDK4 expression & [163] & & \\
\hline Myeloperoxidase activity, AP-1 expression, and IL-10 levels & [165] & & \\
\hline TNF- $\alpha$ expression and IL- 6 levels & {$[170]$} & & \\
\hline Sirt1/PGC1- $\alpha$ expression & [183] & & \\
\hline Box-1 protein expression & {$[187]$} & & \\
\hline Tyrosinase activity & [193] & & \\
\hline $\mathrm{Ca}^{2+}$ entry into the cell & [208] & & \\
\hline
\end{tabular}

Abbreviations: ACAT: acetyl coenzyme A cholesterol O-acyltransferase; AChE: acetylcholinesterase; AMPK: AMP-activated protein kinase; AP-1: activator protein-1; BDNF: brainderived neurotrophic factor; BMP: bone morphogenetic protein; CDK4: cyclin-dependent kinase 4; CK-MB: creatine kinase-MB; COX: cyclooxygenase; CRP: C-reactive protein; CYP: cytochrome P 450; DPP-IV: dipeptidyl peptidase-IV; DR-5: death receptor-5; eNOS: endothelial nitric oxide synthase; ERK: extracellular signal-regulated kinase; ER $\alpha$ : estrogen re-

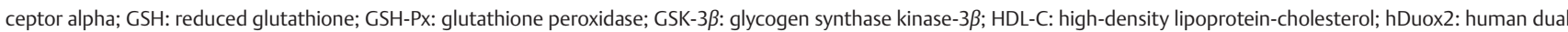
oxidase 2; HMG-CoA: 3-hydroxy-3-methyl-glutaryl-CoA reductase; HSP: heat shock protein; ICAM-1: intercellular adhesion molecule-1; IKK: IKB kinase; IL: interleukin; iNOS: inducible nitric oxide synthase; IRS-1: insulin receptor substrate-1; JNK: Jun NH2-terminal protein kinase; LDH: lactate dehydrogenase; LDL-C: low-density lipoprotein-cholesterol; LXR $\alpha$ : liver X receptor- $\alpha$; MCP-1: monocyte chemotactic protein-1; MDR-1: multidrug resistance-1; MIP-1 $\alpha$ : macrophage inflammatory protein-1 $\alpha$; MMP-9: matrix metalloproteinase-9; MRP-1: multidrug resistance-associated proteins; mTOR: mammalian target of rapamycin; NF-kB: nuclear factor-Kappa B; NK: neurokinin; nNOS: neuronal nitric oxide synthase; NO: nitric oxide; Nrf2: nuclear factor eythroid 2-related factor-2; OATP1A2: organic anion transporting polypeptide; p38MAPK: p38 mitogen-activated protein inase; PARP: poly (ADPribose) polymerase; $\mathrm{PGE}_{2}$ : prostaglandin $\mathrm{E}_{2}$; P-gp: P-glycoprotein; PI3K: phosphatidylinositide 3-kinase; PPAR-y: peroxisome proliferator-activated receptor gamma; Runx2: runtrelated transcription factor 2; SEK-1: stress-activated protein kinase; Sirt1/PGC1- $\alpha$ : silent mating-type information regulation 2 homolog-1/peroxisome proliferator-activated receptor gamma coactivator; SOD: superoxide dismutase; sPLA2: secretory phospholipase A2; SREBP-1c: sterol regulatory element binding protein-1c; SULT: sulfotransferase; TBARS: thiobarbituric acid reactive substance; TC: total cholesterol; TNF- $\alpha$ : tumor necrosis factor-alpha; VEGF: vascular endothelial growth factor

tion (similar to metformin), blocking of the MAPK pathways, and by activation of IRS-1 [129]. As an extension of their in vitro study, Parmar and associates have reported a greater inhibitory effect of naringin $(40 \mathrm{mg} / \mathrm{kg}$, twice daily) on DPP-IV compared to equivalent doses of sitagliptin in diabetic rats [124]. However, Xu- lu and coworkers reported an improvement in the atherogenic index but not hyperglycemia in type 1 diabetic rats with the administration of naringin $(50 \mathrm{mg} / \mathrm{kg})$ [130]. 


\section{Diabetic complications}

Apart from an improvement in diabetes per se, another effect, and perhaps, more important, is the potential of naringin to retard as well as improve diabetic complications, as outlined below. Dietary supplementation with naringin $(100 \mathrm{mg} / \mathrm{kg})$ improved glucose intolerance, plasma lipid concentrations, and liver mitochondrial dysfunction in rats [131]. Pretreatment with naringin (40 and $80 \mathrm{mg} / \mathrm{kg}$ ) also dose-dependently ameliorated STZ-induced diabetic neuropathy and partially reversed the pain response [132]. Naringin $(10 \mathrm{mg} / \mathrm{kg})$ also effectively reduced lens aldose reductase activity in diabetic rats and therefore could delay the progression of cataracts [133]. Moreover, a study from our lab has also revealed that the upregulation of PPARr and heat shock proteins 27 and 72 by naringin $(25,50$ and $100 \mathrm{mg} / \mathrm{kg}$ ) attenuates insulin resistance, $\beta$-cell dysfunction and associated hepatic steatosis, and kidney damage in a rat model of type 2 diabetes [134].

\section{Neuroprotection}

In vitro: Naringin (2, 5 and $10 \mu \mathrm{M})$ has shown dose-dependent protective effects on rotenone-induced cell death in human neuroblastoma SH-SY5Y cells by reducing the activity of caspase-3, caspase-9, and PARP, and inhibiting JNK and p38 phosphorylation [135].

In vivo: The support for the beneficial effect exerted by naringin in studies on Alzheimer's disease is substantial. Wang et al. suggested that naringin (50 and $100 \mathrm{mg} / \mathrm{kg}$ ) substantially alleviated cognitive deficits in an APPswe/PSAE9 transgenic mouse model of Alzheimer's disease through the inhibition of GSK-3 $\beta$ [136]. Naringin $(80 \mathrm{mg} / \mathrm{kg})$ also exhibited memory-enhancing activity in unstressed and stressed mice owing to suppression of brain acetylcholinesterase activity and the decrease of nNOS [137]. Apart from Alzheimer's disease, naringin (50 and $100 \mathrm{mg} / \mathrm{kg}$ ) has shown a protective effect against ischemia reperfusion-induced cerebral injury in rats [138]. Naringin (20 and $40 \mathrm{mg} / \mathrm{kg}$ ) started 1 day after spinal cord injury in rats promoted neuronal recovery by decreasing apoptosis and augmenting BDNF and VEGF expression [139]. Naringin ( 40 and $80 \mathrm{mg} / \mathrm{kg}$ ) has also protected rat brains from colchicine-induced and D-galactose-induced cognitive dysfunction $[140,141]$. Another study highlights the therapeutic potential of naringin $(50 \mathrm{mg} / \mathrm{kg}$ ) against 3-nitropropionic acid-induced Huntington's-like symptoms in rats via modulation of the nitric oxide pathway [142]. It has also been reported that naringin (50 and $100 \mathrm{mg} / \mathrm{kg}$ ) improves post-stroke depression in mice through nitric oxide modulation [143]. In an elevated plus maze model of anxiety, naringin $(30 \mathrm{mg} / \mathrm{kg}$ ) demonstrated a strong anxiolytic effect [144]. Naringin (50 and $100 \mathrm{mg} / \mathrm{kg}$ ) has also shown protection against immobilization stress-induced biochemical and behavioral alterations and mitochondrial dysfunction in mice [145]. Naringin (50, 100, and $200 \mathrm{mg} / \mathrm{kg}$ ) also significantly alleviated antigen-induced chronic fatigue in a mouse model of water immersion stress via decreasing immobility time, hyperalgesia, and TNF- $\alpha$ levels [146].

\section{Hepatoprotection}

In vitro: Naringin at a concentration of $1000 \mu \mathrm{M}$ inhibited PhIPinduced genotoxicity in human liver slices, highlighting a protective effect against naturally occurring genotoxins in food such as $\mathrm{PhIP}$ and other cooked food mutagens [147]. Naringin $(100 \mu \mathrm{M})$ also possesses tremendous potential in protecting rat hepatocytes from environmental toxins such as okadaic acid and microcystin-LR-induced overphosphorylation, disruption of the kera- tin cytoskeletal network, and apoptotic cell death, though it was ineffective in preventing toxin-induced apoptosis of human or rat hepatoma cells [148]. Likewise, in another study by Berven and colleagues, naringin $(100 \mu \mathrm{M})$ has exerted protective effects in isolated rat hepatocytes against okadaic acid-induced apoptotic cell death and disruption of the keratin intermediate filament network and canalicular sheaths, though these effects could not be replicated in vivo [149]. In other studies, it significantly prevented the okadaic acid-induced inhibition of hepatocyte autophagy and endocytosis at a dose range of 5-100 $\mu \mathrm{M}$ [150] and phosphorylation of intracellular proteins in rat hepatocytes such as glycine $\mathrm{N}$-methyltransferase at a dose of $100 \mu \mathrm{M}$ [151] and plectin at dose of $100 \mu \mathrm{M}$ [152].

In vivo: Naringin $(0.05-0.125 \mathrm{~g} / \mathrm{L})$ alleviated the adverse effects of ethanol ingestion in rats by increasing ethanol and lipid metabolism [153]. At a dose of $100 \mathrm{mg} / \mathrm{day}$, it also inhibited steatosis, necrosis, and fibrosis, as evidenced in a rat model of alcoholic liver disease, probably via the decreased expression of Sirt1/PGC1- $\alpha$ (enzymes involved in regulating energy metabolism in response to calorie restriction) [154].

\section{Cancers}

The therapeutic potential of naringin has been elucidated in myriad malignancies as follows:

Breast cancer: Naringin has been shown to inhibit the proliferation of human breast carcinoma MDA-MB-435 cells in vitro as well as DMBA-induced mammary tumor formation in female Sprague-Dawley rats [155]. Molecular docking has also shown naringin to potentially inhibit estrone sulfatase and, hence, attenuate the hormonal stimulation of breast cancer cells [156]. Experiments on ER ( + ) MCF-7 and MDA-MB-231 breast cancer cells have concluded that naringin $\left(0.86 \times 10^{-5}-17.2 \times 10^{-5} \mathrm{M}\right)$ possesses both estrogenic (at low concentrations) and antiestrogenic (at high concentrations) activities primarily through selectively binding with estrogen receptors alpha and beta (ER $\alpha$ and ER $\beta$ ) [157]. Schindler and Mentlein demonstrated that naringin $(0.1 \mu \mathrm{mol} / \mathrm{L})$ significantly inhibited the release of VEGF from MDA breast cancer cells and, hence, reduced the occurrence of angiogenesis, which is one of the initiating factors for distant metastases of cancer cells [158].

Colon cancer: Naringin (1-300 $\mu \mathrm{M})$ has been shown to induce migration of murine immortomouse/Min colon epithelial, $\mathrm{Apc}^{ \pm}$cells through modulation of matrix metalloproteinase activity, thus enhancing the differentiation of these cells and reducing the accumulation of mutations [159]. Similarly, naringin $(200 \mathrm{mg} / \mathrm{kg})$ also ameliorated azoxymethane-induced aberrant crypt foci formation in rats by suppressing proliferation and increasing apoptosis of colon epithelial cells [160]. Naringin (100 and $200 \mathrm{mg} /$ $\mathrm{kg}$ ) accelerated the regression of preneoplastic lesions and the colorectal structural reorganization in a rat model of 1,2-dimethylhydrazine-induced carcinogenesis [161].

Genito-urinary tract cancer: Pretreatment with naringin stimulated death receptor and mitochondria-mediated apoptosis and, hence, reduced survival of human cervical SiHa cancer cells with an $\mathrm{IC}_{50}$ of $750 \mu \mathrm{M}$ [162]. In human 5637 bladder cancer cells, naringin $(0-150 \mu \mathrm{M})$ dose-dependently inhibited the cell growth and proliferation by activating the Ras/Raf/-dependent ERK signaling pathway [163].

Lung cancer: In A549 human lung cancer cell lines, naringin $(23 \mu \mathrm{M})$ suppressed the enhancing effect of beta-carotene on DNA damage induced by NNK, a potent tobacco-related carcinogen in humans [164]. In the same cell line model, naringin 
$(100 \mu \mathrm{M})$ also reduced EGF-induced MUC5AC secretion through the inhibition of MAPKs/AP-1 and IKKs/IkB/NF- $k$ B signaling pathways [165].

Liver cancer: Naringin ( $40 \mathrm{mg} / \mathrm{kg}$ ) has been shown to offer significant protection in $\mathrm{N}$-nitrosodiethylamine-induced $(200 \mathrm{mg} / \mathrm{kg}$ ) liver carcinogenesis in rats [166].

Cancers of the oral cavity: In a hamster cheek pouch model, naringin $(0.20-0.25 \mathrm{mg} / \mathrm{kg})$ significantly reduced the tumor burden in DMBA-induced oral cancer [167].

Skin cancer: In an in vitro study on human keratinocytes and fibroblasts, naringin ( $100 \mathrm{nM}$ ) prevented the formation of double strand DNA breaks following exposure to UV-A radiation, which is considered to be an important etiological factor for skin cancer in humans [168].

Soft tissue tumors: Oral administration of naringin $(30-300 \mathrm{mg} /$ $\mathrm{kg}$ ) inhibited tumor growth in sarcoma S-180-implanted mice [169]. In rats with Walker 256 carcinosarcoma, naringin ( $25 \mathrm{mg} /$ $\mathrm{kg}$ ) suppressed tumor growth by approximately $75 \%$ through decreasing IL-6 and TNF- $\alpha$ levels [170].

Interaction with other anticancer agents: In Ehrlich ascites tumor bearing mice, naringin $(100 \mathrm{mg} / \mathrm{kg})$ enhanced the tumor cell growth inhibition (cytotoxic effect) of irinotecan $(50 \mathrm{mg} / \mathrm{kg}$ ) as the combination demonstrated a greater suppression of liver cancer cells $[171,172]$.

\section{Bone diseases}

Isoflavonoids isolated from plants have been suggested to fight osteoporosis and promote bone health, as documented in the following studies:

In vitro: In rat osteoblast-like UMR-106 cells, naringin ( $10 \mathrm{nM}$ to $1 \mu \mathrm{M})$ increased cell proliferation and ALP activity [173]. Similarly, in the same cell line model, naringin $(0.1-0.001 \mu \mathrm{mol} / \mathrm{L})$, in a dose-dependent fashion, augmented osteoblastic activity via the inhibition of HMG-CoA reductase [174]. Naringin (0.3$10 \mu \mathrm{M}$ ) has been shown to enhance alkaline phosphatase activity, the osteocalcin level, osteopontin synthesis, and cell proliferation in primary cultured osteoblasts [175]. Naringin has also been shown to improve osteogenic proliferation and differentiation in MC3T3-E1 cells via upregulation of Runx2, COLI, and OCN protein expressions (at a dose of $2 \mu \mathrm{g} / \mathrm{mL}$ ) [176] as well as modulation of BMP-2, alkaline phosphatase, and osteocalcin (at a dose of 0.1$10 \mu \mathrm{mol} / \mathrm{L}$ ) [177]. However, the same study by Ding and coworkers failed to show any significant effect on cell calcification [177]. Naringin $(1-100 \mu \mathrm{g} / \mathrm{mL})$ also enhanced the proliferation and osteogenic differentiation of human bone mesenchymal stem cells [178].

In vivo: Naringin has been shown to prevent bone loss following an ovariectomy in C57/BL6J mice when administered at 0.2$0.4 \mathrm{mg} / \mathrm{g}$ [173]. Wu and coworkers proposed that naringin $(0.1 \mathrm{mg} / \mathrm{kg}$ ) prevented the decrease of BMP-2 (protein involved in osteoblastic differentiation and bone formation) and, hence, significantly reduced the bone loss in response to ovariectomies in mice [175]. The estrogenic property of naringin at a dose of $100 \mathrm{mg} / \mathrm{mL}$ has also been reported to enhance new bone formation in New Zealand white rabbits [179]. It also improved bone quality in orchidectomized rats at a dose of $200 \mathrm{mg} / \mathrm{L}$ [180]. This was further confirmed in diabetic mice by Zhou and coworkers who demonstrated that naringin $(10 \mathrm{mg} / \mathrm{kg})$ restores the calvarial thickness and bone volume almost towards normal along with an increase in the concentration of osteocalcin [181]. Naringin improved bone mineral density by $10.2 \%$ at the distal metaphyseal area at a dose of $5 \mathrm{~g} / \mathrm{L}$ [182] as well as the alveolar bone at a dose range from 0.01 to $100 \mathrm{mg} / \mathrm{L}$ [183] in rats, providing evidence for the attenuation of bone resorption. More recent studies have further shown that in addition to osteoclast differentiation, naringin also abrogates osteoclastogenesis at a dose of $1-100 \mu \mathrm{g} / \mathrm{mL}$ [184] and bone resorption via the inhibition of RANKL-induced NF- $k B$ and ERK activation at a dose range of 0.1-0.5 mM [185]. In another study, naringin treatment $(20-100 \mathrm{mg} / \mathrm{kg})$ significantly normalized the serum alkaline phosphatase and bone weight coefficient, and resulted in a higher femur bone mineral density in a model of retinoic acid-induced osteoporosis in rats [186]. Naringin $(15-150 \mathrm{mg} / \mathrm{kg}$ ) has been shown to inhibit the onset of collagen-induced arthritis in the joints of mice via inhibition of Box-1 protein expression as a consequence of its anti-inflammatory action [187].

\section{Dentistry}

In vitro: Naringin $(0.1 \mu \mathrm{M})$ has been shown to augment the growth of the spheno-occipital synchondrosis via increased Sox9 levels [188]. It (0.01-100 mg/L) also promotes the proliferation of human periodontal ligament cells via modulating alkaline phosphatase activity, collagen protein- 1 expression, and osteoprotegerin mRNA levels [189]. It $(0.0625-0.25 \mathrm{~g} / \mathrm{mL})$ also interferes with the growth of periodontal pathogens such as Actinobacillus actinomycetemcomitans and Porphyromonas gingivalis [190].

In vivo: Dietary supplementation with naringin in experimental animals has shown significant beneficial effects on dental health and development. Dietary naringin $(5.7 \mathrm{~g} / \mathrm{kg})$ significantly reduced the molar crestal alveolar bone-cemento-enamel junction distance during alveolar development in young male albino rats [191], as well as the incidence of occlusal dental caries induced by a high-sucrose diet in young rats [192].

\section{Dermatology}

Naringin possess tyrosinase inhibitory activity ( $\mathrm{IC}_{50}$ of $1.9 \mathrm{mM}$ ) and could be useful in skin whitening [193]. It (20 and $50 \mathrm{mg} / \mathrm{kg}$ ) has also prevented the development of picryl chloride-induced contact dermatitis in mice, a type IV allergic reaction [194].

\section{Pulmonary system}

Though naringin is neither a central nor peripheral antitussive, Gao and colleagues observed an antitussive effect of naringin at $30 \mathrm{mg} / \mathrm{kg}$ in guinea pigs due to hitherto unexplored mechanisms [195].

\section{Infections}

Naringin (1 and $3 \mathrm{mg}$ ) resulted in significant protection against Salmonella typhimurium aroA-induced lethal shock in LPS-responder mice via attenuation of TNF- $\alpha$ levels and CD14 and high-mobility group-1 expressions and normalization of prothrombin time, fibrinogen concentration, and platelet numbers [196]. Naringin has been shown to possess antifilarial activity in vitro against Brugia malayi with an $\mathrm{IC}_{50}$ of $78.8 \pm 11.5 \mu \mathrm{g} / \mathrm{mL}$ against female adult worms [197], as well as weak anti-dengue activity with anti-adsorption effects against dengue virus type-2 with an $\mathrm{IC}_{50}$ of $168.2 \mu \mathrm{g} / \mathrm{mL}$ [198]. Furthermore, naringin (20$250 \mu \mathrm{g} / \mathrm{ml}$ ) does not inhibit the growth of the normal commensal bacteria in the gut and, hence, does not increase the risk of superinfections [199]. Similarly, Celiz and associates also observed that naringin did not inhibit any bacterial growth at a concentration of $0.25 \mathrm{mmol} / \mathrm{L}$ [200]. 


\section{Allergies}

Lambev and colleagues demonstrated that naringin $(200 \mathrm{mg} / \mathrm{kg})$ inhibited mastocystic histamine release induced by compound 48/80 in male albino rats; however, it did not affect the histamine levels in the blood [201]. In another study, naringin $(0.1$ or $1 \mathrm{mM}$ and $1.0 \mathrm{mg} / \mathrm{kg}$, respectively) significantly inhibited compound 48/80-induced histamine release from rat peritoneal mast cells and IgE-dependent passive cutaneous anaphylaxis reaction in mice via inhibiting IL-6 levels. Moreover, in the same study, naringin $(0.1$ or $1 \mathrm{mg} / \mathrm{kg}$ ) also decreased clinical symptoms and proinflammatory cytokines levels in the allergic rhinitis in mice [202]. In another study by Itoh et al., naringin $(20-100 \mathrm{mg} / \mathrm{kg})$ dose-dependently inhibited DNFB-induced triphasic cutaneous reaction (ear swelling) at $1 \mathrm{~h}$ (immediate phase response), $24 \mathrm{~h}$ (late phase response), and 8 days (very late phase response) after DNFB challenge, an animal model for type I allergic reaction [194].

\section{Gastrointestinal tract}

Naringin $(200 \mathrm{mg} / \mathrm{kg})$ has significantly reduced the ulcer index and improved gastric mucosal morphology in acetylsalicylic acid-induced ulceration in rats [203]. Moreover, naringin (400 mg/ $\mathrm{kg}$ ) has also been shown to prevent the development of gastric ulcers following ethanol ingestion in rats, presumably by mechanisms not involving prostaglandins [204]. In another model of gastrointestinal motility dysfunction, naringin $(50 \mathrm{mg} / \mathrm{kg}$, orally and $5 \mathrm{mg} / \mathrm{kg}$, i. v.) has been shown to exhibit in vivo prokinetic activity via activation of ghrelin receptors [205].

\section{Experimental tool}

Activation of Kir 3.4 by naringin $(100 \mu \mathrm{M})$ has been shown to hamper angiotensin-II-stimulated membrane voltage and aldosterone secretion, and therefore could be useful as an experimental tool in the study of aldosterone production from the adrenal glands [206]. In addition, experiments on rat vas deferens have shown that naringin $\left(2 \times 10^{-6}-1 \times 10^{-7} \mathrm{M}\right)$ is a better $\alpha_{2}$ agonist than clonidine, thus suggesting its employment as an experimental drug to detect the $\alpha$-receptor modulation of newly designed or discovered molecules [207]. In a study by Shaik and colleagues, naringin $(0-40 \mu \mathrm{M})$ was shown to inhibit suicidal erythrocyte death via suppressing the calcium entry and therefore could be of importance in related cell signaling pathways [208].

\section{Conclusion}

$\nabla$

Thus, the aforementioned data suggests that naringin possesses therapeutic potential in various human disorders. Nevertheless, the employment of naringin in clinical therapy is fraught with numerous shortcomings, as of today. Firstly, the amount of data on the use of naringin in humans is very limited and, as such, the accurate effect of naringin in these human disorders, if any, can merely be predicted. Therefore, further clinical studies are imperative to determine a conclusive role for naringin in human therapeutics. Secondly, naringin is a normal dietary constituent. As such, the regular intake of food would undoubtedly introduce naringin into the human body, but it is unclear whether this administration is sufficient to meet the therapeutic levels in humans, or if additional external supplementation is indispensable. Moreover, the duration of which naringin should be administered is also unclear, as it is unlikely that a short-term intake of naringin would lead to therapeutic improvement. The effect of naringin may only be reached by a continuous uptake. Thirdly, the significant potential of naringin for drug interactions should also receive due consideration when used concomitantly with other allopathic medications. Nevertheless, naringin does seem to represent the light at the end of the tunnel as a supportive remedy for allopathic treatment considering its wide range of purported efficacy and the relatively lesser incidence of adverse reactions.

\section{Acknowledgments}

$\nabla$

The authors gratefully acknowledge the Department of Science and Technology, Government of India for providing fellowships to Saurabh Bharti (IF10332) and Neha Rani (IF120584) under the INSPIRE-DST-Fellowship program. Due to the limitation of space, we would like to apologize to those whose significant work could not be incorporated in the present review article.

\section{Conflict of Interest}

$\nabla$

No competing interests exist.

\section{References}

1 Rangaswami S, Seshadri TR, Veeraraghaviah J. Constitution of naringin. The position of the sugar group. J Proc Ind Acad Sci 1939; 9: 328-332

2 Sinclair WB. The grapefruit: its composition, physiology \& products. Berkeley: UC ANR publications; 1972: 134

3 Ho PC, Saville DJ, Coville PF, Wanwimolruk S. Content of CYP3A4 inhibitors, naringin, naringenin and bergapten in grapefruit and grapefruit juice products. Pharm Acta Helv 2000; 74: 379-385

4 Hungria M, Johnston AW, Phillips DA. Effects of flavonoids released naturally from bean (Phaseolus vulgaris) on nodD-regulated gene transcription in Rhizobium leguminosarum bv. phaseoli. Mol Plant Microbe Interact 1992; 5: 199-203

5 Wang H, Nair MG, Strasburg GM, Booren AM, Gray JI. Antioxidant polyphenols from tart cherries (Prunus cerasus). J Agric Food Chem 1999; 47: 840-844

6 Sánchez-Rabaneda F, Jáuregui O, Casals I, Andrés-Lacueva C, IzquierdoPulido M, Lamuela-Raventós RM. Liquid chromatographic/electrospray ionization tandem mass spectrometric study of the phenolic composition of cocoa (Theobroma cacao). J Mass Spectrom 2003; 38: 35-42

7 Exarchou V, Godejohann M, van Beek TA, Gerothanassis IP, Vervoort J. LC-UV-solid-phase extraction-NMR-MS combined with a cryogenic flow probe and its application to the identification of compounds present in Greek oregano. Anal Chem 2003; 75: 6288-6294

8 Minoggio M, Bramati L, Simonetti P, Gardana C, Iemoli L, Santangelo E, Mauri PL, Spigno P, Soressi GP, Pietta PG. Polyphenol pattern and antioxidant activity of different tomato lines and cultivars. Ann Nutr Metab 2003; 47: 64-69

9 Rouseff RL, Martin SF, Youtsey CO. Quantitative survey of narirutin, naringin, hesperidin, and neohesperidin in citrus. J Agric Food Chem 1987; 35: $1027-1030$

10 Asahina $Y$, Inubuse M. Über die Konstitution des Naringenins (II. Mitteilung über die Flavanon-Glucoside). Chemische Berichte 1928; 61: 1514

11 Braverman JBS. Citrus products. Chemical composition and chemical technology. New York: Interscience Publishers; 1949: 424

12 Tomasik P. Chemical and functional properties of food saccharides. Boca Raton: CRC Press; 2004: 389

13 Wilcox LJ, Borradaile NM, Huff MW. Antiatherogenic properties of naringenin, a citrus flavonoid. Cardiovasc Drug Rev 1999; 17: 160-178

14 Chanet A, Milenkovic D, Manach C, Mazur A, Morand C. Citrus flavanones: what is their role in cardiovascular protection? J Agric Food Chem 2012; 60: 8809-8822

15 Benavente-García O, Castillo J. Update on uses and properties of citrus flavonoids: new findings in anticancer, cardiovascular, and anti-inflammatory activity. J Agric Food Chem 2008; 56: 6185-6205 
16 Liu M, Yang C, Zou W, Guan X, Zheng W, Lai L, Fang S, Cai S, Su W. Toxicokinetics of naringin, a putative antitussive, after 184-day repeated oral administration in rat. Environ Toxicol Pharmacol 2011; 31: 485489

17 Wang MJ, Chao PDL, Hou YC, Hsiu SL, Wen KC, Tsai SY. Pharmacokinetics and conjugation metabolism of naringin and naringenin in rats after single dose and muliple dose administration. J Food Drug Anal 2006; 14: $247-253$

18 Tsai YJ, Tsai TH. Mesenteric lymphatic absorption and the pharmacokinetics of naringin and naringenin in the rat. J Agric Food Chem 2012; 60: 12 435-12 442

19 Fang T, Wang Y, Ma Y, Su W, Bai Y, Zhao P. A rapid LC/MS/MS quantitation assay for naringin and its two metabolites in rats plasma. J Pharm Biomed Anal 2006; 40: 454-459

20 Felgines C, Texier O, Morand C, Manach C, Scalbert A, Régerat F, Rémésy C. Bioavailability of the flavanone naringenin and its glycosides in rats. Am J Physiol Gastrointest Liver Physiol 2000; 279: G1148-G1154

21 Hsiu SL, Huang TY, Hou YC, Chin DH, Chao PD. Comparison of metabolic pharmacokinetics of naringin and naringenin in rabbits. Life Sci 2002; 70: $1481-1489$

22 Liu M, Zou W, Yang C, Peng W, Su W. Metabolism and excretion studies of oral administered naringin, a putative antitussive, in rats and dogs. Biopharm Drug Dispos 2012; 33: 123-134

23 Mata-Bilbao Mde L, Andrés-Lacueva C, Roura E, Jáuregui O, Escribano E, Torre C, Lamuela-Raventós RM. Absorption and pharmacokinetics of grapefruit flavanones in beagles. Br J Nutr 2007; 98: 86-92

24 Ishii K, Furuta T, Kasuya Y. Determination of naringin and naringenin in human urine by high-performance liquid chromatography utilizing solid-phase extraction. J Chromatogr B Biomed Sci Appl 1997; 704: 299-305

25 Ameer B, Weintraub RA, Johnson JV, Yost RA, Rouseff RL. Flavanone absorption after naringin, hesperidin, and citrus administration. Clin Pharmacol Ther 1996; 60: 34-40

26 Kanaze FI, Kokkalou E, Georgarakis M, Niopas I. A validated solid-phase extraction HPLC method for the simultaneous determination of the citrus flavanone aglycones hesperetin and naringenin in urine. J Pharm Biomed Anal 2004: 36: 175-181

27 Kim DH, Jung EA, Sohng IS, Han JA, Kim TH, Han MJ. Intestinal bacterial metabolism of flavonoids and its relation to some biological activities. Arch Pharm Res 1998; 21: 17-23

28 Griffiths LA, Smith GE. Metabolism of myricetin and related compounds in the rat. Metabolite formation in vivo and by the intestinal microflora in vitro. Biochem J 1972; 130: 141-151

29 Griffiths LA, Barrow A. Metabolism of flavonoid compounds in germfree rats. Biochem J 1972; 130: 1161-1162

30 Nikolic D, van Breemen RB. New metabolic pathways for flavanones catalyzed by rat liver microsomes. Drug Metab Dispos 2004; 32: 387-397

31 Li X, Xiao H, Liang X, Shi D, Liu J. LC-MS/MS determination of naringin, hesperidin and neohesperidin in rat serum after orally administrating the decoction of Bulpleurum falcatum $L$. and Fractus aurantii. J Pharm Biomed Anal 2004; 27: 159-166

32 Zou W, Yang C, Liu M, Su W. Tissue distribution study of naringin in rats by liquid chromatography-tandem mass spectrometry. Arzneimittelforschung 2012; 62: 181-186

$33 \mathrm{Tsai}$ TH. Determination of naringin in rat blood, brain, liver, and bile using microdialysis and its interaction with cyclosporin a, a p-glycoprotein modulator. J Agric Food Chem 2002; 50: 6669-6674

34 Fuhr U, Kummert AL. The fate of naringin in humans: a key to grapefruit juice-drug interactions? Clin Pharmacol Ther 1995; 58: 365-373

35 Shirasaka Y, Suzuki K, Shichiri M, Nakanishi T, Tamai I. Intestinal absorption of HMG-CoA reductase inhibitor pitavastatin mediated by organic anion transporting polypeptide and P-glycoprotein/multidrug resistance 1. Drug Metab Pharmacokinet 2011; 26: 171-179

36 Yamakawa Y, Hamada A, Shuto T, Yuki M, Uchida T, Kai H, Kawaguchi T, Saito $H$. Pharmacokinetic impact of SLCO1A2 polymorphisms on imatinib disposition in patients with chronic myeloid leukemia. Clin Pharmacol Ther 2011; 90: 157-163

37 Nishimuta H, Ohtani $H$, Tsujimoto M, Ogura K, Hiratsuka A, Sawada Y. Inhibitory effects of various beverages on human recombinant sulfotransferase isoforms SULT1A1 and SULT1A3. Biopharm Drug Dispos 2007; 28: 491-500

38 Walle T, Eaton EA, Walle UK. Quercetin, a potent and specific inhibitor of the human P-form phenosulfotransferase. Biochem Pharmacol 1995; 50: 731-734
39 Dahan A, Amidon GL. Grapefruit juice and its constituents augment colchicine intestinal absorption: potential hazardous interaction and the role of p-glycoprotein. Pharm Res 2009; 26: 883-892

40 Yeum $\mathrm{CH}$, Choi JS. Effect of naringin pretreatment on bioavailability of verapamil in rabbits. Arch Pharm Res 2006; 29: 102-107

$41 \mathrm{Lim}$ SC, Choi JS. Effects of naringin on the pharmacokinetics of intravenous paclitaxel in rats. Biopharm Drug Dispos 2006; 27: 443-447

42 Park HS, Oh JH, Lee JH, Lee YJ. Minor effects of the citrus flavonoids naringin, naringenin and quercetin, on the pharmacokinetics of doxorubicin in rats. Pharmazie 2011; 66: 424-429

43 Ballard TL, Halaweish FT, Stevermer CL, Agrawal P, Vukovich MD. Naringin does not alter caffeine pharmacokinetics, energy expenditure, or cardiovascular haemodynamics in humans following caffeine consumption. Clin Exp Pharmacol Physiol 2006; 33: 310-314

44 Ali MM, Agha FG, El-Sammad NM, Hassan SK. Modulation of anticancer drug-induced P-glycoprotein expression by naringin. Z Naturforsch C 2009; 64: 109-116

45 Guengerich FP, Kim DH. In vitro inhibition of dihydropyridine oxidation and aflatoxin B1 activation in human liver microsomes by naringenin and other flavonoids. Carcinogenesis 1990; 11: 2275-2279

46 Chen YT, Zheng RL, Jia ZJ, Ju Y. Flavonoids as superoxide scavengers and antioxidants. Free Radic Biol Med 1990; 9: 19-21

47 Russo A, Acquaviva R, Campisi A, Sorrenti V, Di Giacomo C, Virgata G, Barcellona ML, Vanella A. Bioflavonoids as antiradicals, antioxidants and DNA cleavage protectors. Cell Biol Toxicol 2000; 16: 91-98

48 Maridonneau-Parini IR, Braquet P, Garay RP. Heterogeneous effect of flavonoids on $\mathrm{K}^{+}$-loss and lipid peroxidation induced by oxygen free radicals in human red cells. Pharmacol Res Commun 1986; 18: 61-72

49 Kumar MS, Unnikrishnan MK, Patra S, Murthy K, Srinivasan KK. Naringin and naringenin inhibit nitrite-induced methemoglobin formation. Pharmazie 2003; 58: 564-566

50 Karaseva EI, Kurchenko VP, Metelitsa DI. Flavonoids: efficient protectors of glucose-6-phosphate dehydrogenase from ultrasonic cavitation-induced inactivation. Prikl Biokhim Mikrobiol 2007; 43: 158-168

51 Zielińska-Przyjemska M, Ignatowicz E. Citrus fruit flavonoids influence on neutrophil apoptosis and oxidative metabolism. Phytother Res 2008: 22: 1557-1562

52 Jagetia GC, Reddy TK, Venkatesha VA, Kedlaya R. Influence of naringin on ferric iron induced oxidative damage in vitro. Clin Chim Acta 2004; 347: 189-197

53 Jagetia GC, Reddy TK. Alleviation of iron induced oxidative stress by the grape fruit flavanone naringin in vitro. Chem Biol Interact 2011; 190: 121-128

54 Kim SW, Kim CE, Kim MH. Flavonoids inhibit high glucose-induced upregulation of ICAM-1 via the $\mathrm{p} 38$ MAPK pathway in human vein endothelial cells. Biochem Biophys Res Commun 2011; 415: 602-607

55 Chen J, Guo R, Yan H, Tian L, You Q Li S, Huang R, Wu K. Naringin Inhibits ROS-activated MAPK Pathway in High Glucose-induced Injuries in H9c2 Cardiac Cells. Basic Clin Pharmacol Toxicol 2014; 114: 293-304

$56 \mathrm{Lu} \mathrm{YH}$, Su MY, Huang HY, Lin-Li, Yuan CG. Protective effects of the citrus flavanones to PC12 cells against cytotoxicity induced by hydrogen peroxide. Neurosci Lett 2010; 484: 6-11

57 Gopinath $K$, Sudhandiran G. Naringin modulates oxidative stress and inflammation in 3-nitropropionic acid-induced neurodegeneration through the activation of nuclear factor-erythroid 2-related factor-2 signalling pathway. Neuroscience 2012; 227: 134-143

58 Gopinath K, Prakash D, Sudhandiran G. Neuroprotective effect of naringin, a dietary flavonoid against 3-nitropropionic acid-induced neuronal apoptosis. Neurochem Int 2011; 59: 1066-1073

59 Kanno S, Shouji A, Asou K, Ishikawa M. Effects of naringin on hydrogen peroxide-induced cytotoxicity and apoptosis in P388 cells. J Pharmacol Sci 2003; 92: 166-170

60 Kanno S, Shouji A, Hirata R, Asou K, Ishikawa M. Effects of naringin on cytosine arabinoside (Ara-C)-induced cytotoxicity and apoptosis in P388 cells. Life Sci 2004; 75: 353-365

61 Yeh SL, Wang WY, Huang CH, Hu ML. Pro-oxidative effect of beta-carotene and the interaction with flavonoids on UVA-induced DNA strand breaks in mouse fibroblast C3H10 T1/2 cells. J Nutr Biochem 2005; 16: 729-735

62 Benkovic V, Knezevic AH, Orsolic N, Basic I, Ramic S, Viculin T, Knezevic F, Kopjar N. Evaluation of radioprotective effects of propolis and its flavonoid constituents: in vitro study on human white blood cells. Phytother Res 2009; 23: 1159-1168 
63 Yilmaz D, Aydemir NC, Vatan O, Tüzün E, Bilaloglu R. Influence of naringin on cadmium-induced genomic damage in human lymphocytes in vitro. Toxicol Ind Health 2012; 28: 114-121

64 Jagetia A, Jagetia GC, Jha S. Naringin, a grapefruit flavanone, protects V79 cells against the bleomycin-induced genotoxicity and decline in survival. J Appl Toxicol 2007; 27: 122-132

65 Hori M, Kojima H, Nakata S, Konishi H, Kitagawa A, Kawai K. A search for the plant ingredients that protect cells from air pollutants and benz[a] pyrene phototoxicity. Drug Chem Toxicol 2007; 30: 105-116

66 Cavia-Saiz M, Busto MD, Pilar-Izquierdo MC, Ortega N, Perez-Mateos M, Muñiz P. Antioxidant properties, radical scavenging activity and biomolecule protection capacity of flavonoid naringenin and its glycoside naringin: a comparative study. J Sci Food Agric 2010; 90: 1238-1244

67 Pereira RM, Andrades NE, Paulino N, Sawaya AC, Eberlin MN, Marcucci MC, Favero GM, Novak EM, Bydlowski SP. Synthesis and characterization of a metal complex containing naringin and $\mathrm{Cu}$, and its antioxidant, antimicrobial, antiinflammatory and tumor cell cytotoxicity. Molecules 2007; 12: 1352-1366

68 Anh NT, Nishitani M, Harada S, Yamaguchi M, Kamei K. A Drosophila model for the screening of bioavailable NADPH oxidase inhibitors and antioxidants. Mol Cell Biochem 2011; 352: 91-98

69 Bodas R, Prieto N, López-Campos O, Giráldez FJ, Andrés S. Naringin and vitamin $\mathrm{E}$ influence the oxidative stability and lipid profile of plasma in lambs fed fish oil. Res Vet Sci 2011; 91: 98-102

70 Jeon SM, Bok SH, Jang MK, Kim YH, Nam KT, Jeong TS, Park YB, Choi MS. Comparison of antioxidant effects of naringin and probucol in cholesterol-fed rabbits. Clin Chim Acta 2002; 317: 181-190

71 Jeon SM, Bok SH, Jang MK, Lee MK, Nam KT, Park YB, Rhee SJ, Choi MS. Antioxidative activity of naringin and lovastatin in high cholesterolfed rabbits. Life Sci 2001; 69: 2855-2866

72 Singh $D$, Chopra $K$. The effect of naringin, a bioflavonoid on ischemiareperfusion induced renal injury in rats. Pharmacol Res 2004; 50 : 187-193

73 Akondi BR, Challa SR, Akula A. Protective effects of rutin and naringin in testicular ischemia-reperfusion induced oxidative stress in rats. J Reprod Infertil 2011; 12: 209-214

74 Amudha K, Pari L. Beneficial role of naringin, a flavanoid on nickel induced nephrotoxicity in rats. Chem Biol Interact 2011; 193: 57-64

75 Pari L, Amudha K. Hepatoprotective role of naringin on nickel-induced toxicity in male Wistar rats. Eur J Pharmacol 2011; 650: 364-370

76 Singh D, Chander V, Chopra K. Protective effect of naringin, a bioflavonoid on ferric nitrilotriacetate-induced oxidative renal damage in rat kidney. Toxicology 2004; 201: 1-8

77 Singh D, Chander V, Chopra K. Protective effect of naringin, a bioflavonoid on glycerol-induced acute renal failure in rat kidney. Toxicology 2004; 201: 143-151

78 Cariño-Cortés R, Alvarez-González I, Martino-Roaro L, Madrigal-Bujaidar $E$. Effect of naringin on the DNA damage induced by daunorubicin in mouse hepatocytes and cardiocytes. Biol Pharm Bull 2010; 33: 697701

79 Attia SM. Abatement by naringin of lomefloxacin-induced genomic instability in mice. Mutagenesis 2008; 23: 515-521

80 Mahmoud AM, Ashour MB, Abdel-Moneim A, Ahmed OM. Hesperidin and naringin attenuate hyperglycemia-mediated oxidative stress and proinflammatory cytokine production in high fat fed/streptozotocininduced type 2 diabetic rats. J Diabetes Complications 2012; 26: 483490

81 Bakheet SA, Attia SM. Evaluation of chromosomal instability in diabetic rats treated with naringin. Oxid Med Cell Longev 2011; 2011: 365292

82 Jagetia GC, Reddy TK. Modulation of radiation-induced alteration in the antioxidant status of mice by naringin. Life Sci 2005; 77: 780-794

83 Jagetia GC, Venkatesha VA, Reddy TK. Naringin, a citrus flavonone, protects against radiation-induced chromosome damage in mouse bone marrow. Mutagenesis 2003; 18: 337-343

84 Orsolić N, Benković V, Horvat-Knezević A, Kopjar N, Kosalec I, Bakmaz M, Mihaljević Z, Bendelja K, Basić I. Assessment by survival analysis of the radioprotective properties of propolis and its polyphenolic compounds. Biol Pharm Bull 2007; 30: 946-951

85 Kanno S, Shouji A, Tomizawa A, Hiura T, Osanai Y, Ujibe M, Obara Y, Nakahata $N$, Ishikawa $M$. Inhibitory effect of naringin on lipopolysaccharide (LPS)-induced endotoxin shock in mice and nitric oxide production in RAW 264.7 macrophages. Life Sci 2006; 78: 673-681

86 Liu Y, Su WW, Wang S, Li PB. Naringin inhibits chemokine production in an LPS-induced RAW 264.7 macrophage cell line. Mol Med Report 2012; 6 : 1343-1350
87 Si-Si W, Liao L, Ling Z, Yun-Xia Y. Inhibition of TNF- $\alpha /$ IFN- $\gamma$ induced RANTES expression in HaCaT cell by naringin. Pharm Biol 2011; 49: $810-814$

88 Santos ML, Toyama DO, Oliveira SC, Cotrim CA, Diz-Filho EB, Fagundes FH, Soares VC, Aparicio R, Toyama MH. Modulation of the pharmacological activities of secretory phospholipase A2 from Crotalus durissus cascavella induced by naringin. Molecules 2011; 16: 738-761

89 Xiong Y, Wang GF, Zhang JY, Wu SY, Xu W, Zhang JJ, Wu SG, Rao JJ. Naringin inhibits monocyte adhesion to high glucose-induced human umbilical vein endothelial cells. Nan Fang Yi Ke Da Xue Xue Bao 2010; 30: 321-325

90 Lee JH, Kim GH. Evaluation of antioxidant and inhibitory activities for different subclasses flavonoids on enzymes for rheumatoid arthritis. J Food Sci 2010; 75: H212-H217

91 Prota L, Santoro A, Bifulco M, Aquino RP, Mencherini T, Russo P. Leucine enhances aerosol performance of naringin dry powder and its activity on cystic fibrosis airway epithelial cells. Int J Pharm 2011; 412: 8-19

92 Kawaguchi K, Kikuchi S, Hasegawa H, Maruyama H, Morita H, Kumazawa Y. Suppression of lipopolysaccharide-induced tumor necrosis factor-release and liver injury in mice by naringin. Eur J Pharmacol 1999; 368: $245-250$

93 Liu Y, Wu H, Nie YC, Chen JL, Su WW, Li PB. Naringin attenuates acute lung injury in LPS-treated mice by inhibiting NF- $k B$ pathway. Int Immunopharmacol 2011; 11: 1606-1612

94 Shiratori K, Ohgami K, Ilieva I, Jin XH, Yoshida K, Kase S, Ohno S. The effects of naringin and naringenin on endotoxin-induced uveitis in rats. J Ocul Pharmacol Ther 2005; 21: 298-304

95 Nie YC, Wu H, Li PB, Luo YL, Long K, Xie LM, Shen JG, Su WW. Anti-inflammatory effects of naringin in chronic pulmonary neutrophilic inflammation in cigarette smoke-exposed rats. J Med Food 2012; 15 : 894-900

96 Luo YL, Zhang CC, Li PB, Nie YC, Wu H, Shen JG, Su WW. Naringin attenuates enhanced cough, airway hyperresponsiveness and airway inflammation in a guinea pig model of chronic bronchitis induced by cigarette smoke. Int Immunopharmacol 2012; 13: 301-307

97 Luo YL, Li PB, Zhang CC, Zheng YF, Wang S, Nie YC, Zhang KJ, Su WW. Effects of four antitussives on airway neurogenic inflammation in a guinea pig model of chronic cough induced by cigarette smoke exposure. Inflamm Res 2013; 62: 1053-1061

98 Jain M, Parmar HS. Evaluation of antioxidative and anti-inflammatory potential of hesperidin and naringin on the rat air pouch model of inflammation. Inflamm Res 2011; 60: 483-491

99 Amaro MI, Rocha J, Vila-Real H, Eduardo-Figueira M, Mota-Filipe H, Sepodes $B$, Ribeiro $M H$. Anti-inflammatory activity of naringin and the biosynthesised naringenin by naringinase immobilized in microstructured materials in a model of DSS-induced colitis in mice. Food Res Int 2009; 42: 1010-1017

100 Golechha M, Chaudhry U, Bhatia J, Saluja D, Arya DS. Naringin protects against kainic acid-induced status epilepticus in rats: evidence for an antioxidant, anti-inflammatory and neuroprotective intervention. Biol Pharm Bull 2011; 34: 360-365

101 Naderi GA, Asgary S, Sarraf-Zadegan N, Shirvany H. Anti-oxidant effect of flavonoids on the susceptibility of LDL oxidation. Mol Cell Biochem 2003; 246: 193-196

102 Balestrieri ML, Castaldo D, Balestrieri C, Quagliuolo L, Giovane A, Servillo $L$. Modulation by flavonoids of PAF and related phospholipids in endothelial cells during oxidative stress. J Lipid Res 2003; 44: 380-387

103 Lee EJ, Moon GS, Choi WS, Kim WJ, Moon SK. Naringin-induced p21WAF1-mediated G(1)-phase cell cycle arrest via activation of the Ras/Raf/ERK signaling pathway in vascular smooth muscle cells. Food Chem Toxicol 2008; 46: 3800-3807

104 Lee EJ, Kim DI, Kim WJ, Moon SK. Naringin inhibits matrix metalloproteinase-9 expression and AKT phosphorylation in tumor necrosis factor-alpha-induced vascular smooth muscle cells. Mol Nutr Food Res 2009; 53: 1582-1591

105 Shin YW, Bok SH, Jeong TS, Bae KH, Jeoung NH, Choi MS, Lee SH, Park YB. Hypocholesterolemic effect of naringin associated with hepatic cholesterol regulating enzyme changes in rats. Int J Vitam Nutr Res 1999; 69: 341-347

106 Lee CH, Jeong TS, Choi YK, Hyun BH, Oh GT, Kim EH, Kim JR, Han JI, Bok $\mathrm{SH}$. Anti-atherogenic effect of citrus flavonoids, naringin and naringenin, associated with hepatic ACAT and aortic VCAM- 1 and MCP-1 in high cholesterol-fed rabbits. Biochem Biophys Res Commun 2001; 284: 681-688 
107 Choe SC, Kim HS, Jeong TS, Bok SH, Park YB. Naringin has an antiatherogenic effect with the inhibition of intercellular adhesion molecule-1 in hypercholesterolemic rabbits. J Cardiovasc Pharmacol 2001; 38: 947-955

108 Jeon SM, Park YB, Choi MS. Antihypercholesterolemic property of naringin alters plasma and tissue lipids, cholesterol-regulating enzymes, fecal sterol and tissue morphology in rabbits. Clin Nutr 2004; 23: 1025-1034

109 Kim HJ, Oh GT, Park YB, Lee MK, Seo HJ, Choi MS. Naringin alters the cholesterol biosynthesis and antioxidant enzyme activities in LDL receptor-knockout mice under cholesterol fed condition. Life Sci 2004; 74: 1621-1634

110 Kim SY, Kim HJ, Lee MK, Jeon SM, Do GM, Kwon EY, Cho YY, Kim DJ, Jeong KS, Park YB, Ha TY, Choi MS. Naringin time-dependently lowers hepatic cholesterol biosynthesis and plasma cholesterol in rats fed high-fat and high-cholesterol diet. J Med Food 2006; 9: 582-586

111 Chanet A, Milenkovic D, Deval C, Potier M, Constans J, Mazur A, Bennetau-Pelissero $C$, Morand $C$, Bérard AM. Naringin, the major grapefruit flavonoid, specifically affects atherosclerosis development in diet-induced hypercholesterolemia in mice. J Nutr Biochem 2012; 23: 469477

112 Jung UJ, Kim HJ, Lee JS, Lee MK, Kim HO, Park EJ, Kim HK, Jeong TS, Choi MS. Naringin supplementation lowers plasma lipids and enhances erythrocyte antioxidant enzyme activities in hypercholesterolemic subjects. Clin Nutr 2003; 22: 561-568

113 Demonty I, Lin Y, Zebregs YE, Vermeer MA, van der Knaap HC, Jäkel M, Trautwein EA. The citrus flavonoids hesperidin and naringin do not affect serum cholesterol in moderately hypercholesterolemic men and women. J Nutr 2010; 140: 1615-1620

114 Ajay M, Gilani AU, Mustafa MR. Effects of flavonoids on vascular smooth muscle of the isolated rat thoracic aorta. Life Sci 2003; 74: 603-612

115 Saponara S, Testai L, Iozzi D, Martinotti E, Martelli A, Chericoni S, Sgaragli G, Fusi F, Calderone V. ( \pm )-Naringenin as large conductance Ca2+activated $\mathrm{K}+(\mathrm{BKCa})$ channel opener in vascular smooth muscle cells. Br J Pharmacol 2006; 149: 1013-1021

116 Yow TT, Pera E, Absalom N, Heblinski M, Johnston GA, Hanrahan JR, Chebib $M$. Naringin directly activates inwardly rectifying potassium channels at an overlapping binding site to tertiapin-Q. Br J Pharmacol 2011; 163: 1017-1033

117 Huang $H, W u$ K, You $Q$ Huang $R$, Li S, Wu K. Naringin inhibits high glucose-induced cardiomyocyte apoptosis by attenuating mitochondrial dysfunction and modulating the activation of the p38 signaling pathway. Int J Mol Med 2013; 32: 396-402

118 Ikemura M, Sasaki Y, Giddings JC, Yamamoto J. Preventive effects of hesperidin, glucosyl hesperidin and naringin on hypertension and cerebral thrombosis in stroke-prone spontaneously hypertensive rats. Phytother Res 2012; 26: 1272-1277

119 Rajadurai M, Prince PS. Preventive effect of naringin on cardiac mitochondrial enzymes during isoproterenol-induced myocardial infarction in rats: a transmission electron microscopic study. J Biochem Mol Toxicol 2007: 21: 354-361

120 Rajadurai M, Prince PS. Preventive effect of naringin on isoproterenolinduced cardiotoxicity in Wistar rats: an in vivo and in vitro study. Toxicology 2007; 232: 216-225

121 Rajadurai $M$, Prince PS. Preventive effect of naringin on cardiac markers, electrocardiographic patterns and lysosomal hydrolases in normal and isoproterenol-induced myocardial infarction in Wistar rats. Toxicology 2007; 230: 178-188

122 Rajadurai $M$, Prince PS. Preventive effect of naringin on lipid peroxides and antioxidants in isoproterenol-induced cardiotoxicity in Wistar rats: biochemical and histopathological evidences. Toxicology 2006; 228: 259-268

123 Rani N, Bharti S, Manchanda M, Nag TC, Ray R, Chauhan SS, Kumari S, Arya DS. Regulation of heat shock proteins 27 and 70, p-Akt/p-eNOS and MAPKs by naringin dampens myocardial injury and dysfunction in vivo after ischemia/reperfusion. PLoS One 2013; 8: e82577

124 Parmar HS, Jain P, Chauhan DS, Bhinchar MK, Munjal V, Yusuf $M$, Choube K, Tawani A, Tiwari V, Manivannan E, Kumar A. DPP-IV inhibitory potential of naringin: an in silico, in vitro and in vivo study. Diabetes Res Clin Pract 2012; 97: 105-111

125 Purushotham A, Tian M, Belury MA. The citrus fruit flavonoid naringenin suppresses hepatic glucose production from Fao hepatoma cells. Mol Nutr Food Res 2009; 53: 300-307
126 Jung UJ, Lee MK, Jeong KS, Choi MS. The hypoglycemic effects of hesperidin and naringin are partly mediated by hepatic glucose-regulating enzymes in C57BL/KsJ-db/db mice. J Nutr 2004; 134: 2499-2503

127 Jung UJ, Lee MK, Park YB, Kang MA, Choi MS. Effect of citrus flavonoids on lipid metabolism and glucose-regulating enzyme mRNA levels in type-2 diabetic mice. Int J Biochem Cell Biol 2006; 38: 1134-1145

128 Leray V, Freuchet B, Le Bloc'h J, Jeusette I, Torre C, Nguyen P. Effect of citrus polyphenol- and curcumin-supplemented diet on inflammatory state in obese cats. Br J Nutr 2011; 106: S198-S201

129 Pu P, Gao DM, Mohamed S, Chen J, Zhang J, Zhou XY, Zhou NJ, Xie J, Jiang $H$. Naringin ameliorates metabolic syndrome by activating AMP-activated protein kinase in mice fed a high-fat diet. Arch Biochem Biophys 2012; 518: 61-70

130 Xulu S, Oroma Owira PM. Naringin ameliorates atherogenic dyslipidemia but not hyperglycemia in rats with type 1 diabetes. J Cardiovasc Pharmacol 2012; 59: 133-141

131 Alam MA, Kauter K, Brown L. Naringin improves diet-induced cardiovascular dysfunction and obesity in high carbohydrate, high fat dietfed rats. Nutrients 2013; 5: 637-650

132 Kandhare AD, Raygude KS, Ghosh P, Ghule AE, Bodhankar SL. Neuroprotective effect of naringin by modulation of endogenous biomarkers in streptozotocin induced painful diabetic neuropathy. Fitoterapia 2012 83: 650-659

133 Goodarzi MT, Zal F, Malakooti M, Safari MR, Sadeghian S. Inhibitory activity of flavonoids on the lens aldose reductase of healthy and diabetic rats. Acta Medica Iranica 2006; 44: 41-45

134 Sharma AK, Bharti S, Ojha S, Bhatia J, Kumar N, Ray R, Kumari S, Arya $D S$. Up-regulation of PPAR $\gamma$, heat shock protein-27 and -72 by naringin attenuates insulin resistance, $\beta$-cell dysfunction, hepatic steatosis and kidney damage in a rat model of type 2 diabetes. Br J Nutr 2011; 106: $1713-1723$

135 Kim HJ, Song JY, Park HJ, Park HK, Yun DH, Chung JH. Naringin protects against rotenone-induced apoptosis in human neuroblastoma $\mathrm{SH}-$ SY5Y cells. Korean J Physiol Pharmacol 2009; 13: 281-285

136 Wang D, Gao K, Li X, Shen X, Zhang X, Ma C, Qin C, Zhang L. Long-term naringin consumption reverses a glucose uptake defect and improves cognitive deficits in a mouse model of Alzheimer's disease. Pharmacol Biochem Behav 2012; 102: 13-20

137 Maratha SR, Mahadevan N. Memory enhancing activity of naringin in unstressed and stressed mice: possible cholinergic and nitriergic modulation. Neurochem Res 2012; 37: 2206-2212

138 Gaur V, Aggarwal A, Kumar A. Protective effect of naringin against ischemic reperfusion cerebral injury: possible neurobehavioral, biochemical and cellular alterations in rat brain. Eur J Pharmacol 2009 616: $147-154$

139 Rong W, Wang J, Liu X, Jiang L, Wei F, Hu X, Han X, Liu Z. Naringin treatment improves functional recovery by increasing BDNF and VEGF expression, inhibiting neuronal apoptosis after spinal cord injury. Neurochem Res 2012; 37: 1615-1623

140 Kumar A, Dogra S, Prakash A. Protective effect of naringin, a citrus flavonoid, against colchicine-induced cognitive dysfunction and oxidative damage in rats. J Med Food 2010; 13: 976-984

141 Kumar A, Prakash A, Dogra S. Naringin alleviates cognitive impairment, mitochondrial dysfunction and oxidative stress induced by Dgalactose in mice. Food Chem Toxicol 2010; 48: 626-632

142 Kumar P, Kumar A. Protective effect of hesperidin and naringin against 3-nitropropionic acid induced Huntington's like symptoms in rats: possible role of nitric oxide. Behav Brain Res 2010; 206: 38-46

143 Aggarwal A, Gaur V, Kumar A. Nitric oxide mechanism in the protective effect of naringin against post-stroke depression (PSD) in mice. Life Sci 2010; 86: 928-935

144 Fernandez SP, Nguyen M, Yow TT, Chu C, Johnston GA, Hanrahan JR, Chebib $M$. The flavonoid glycosides, myricitrin, gossypin and naringin exert anxiolytic action in mice. Neurochem Res 2009; 34: 1867-1875

145 Viswanatha GL, Shylaja H, Rao KS, Ashwini Y, Kumar VR, Mohan CG, Sunil VG, Kumar MV, Rajesh S. Amelioration of immobilization stress-induced biochemical and behavioral alterations and mitochondrial dysfunction by naringin in mice: possible mechanism of nitric oxide modulation. Zhong Xi Yi Jie He Xue Bao 2011; 9: 1254-1263

146 Vij G, Gupta A, Chopra K. Modulation of antigen-induced chronic fatigue in mouse model of water immersion stress by naringin, a polyphenolic antioxidant. Fundam Clin Pharmacol 2009; 23: 331-337

147 Lake BG, Beamand JA, Tredger JM, Barton PT, Renwick AB, Price RJ. Inhibition of xenobiotic-induced genotoxicity in cultured precision-cut human and rat liver slices. Mutat Res 1999; 440: 91-100 
148 Blankson H, Grotterød EM, Seglen PO. Prevention of toxin-induced cytoskeletal disruption and apoptotic liver cell death by the grapefruit flavonoid, naringin. Cell Death Differ 2000; 7: 739-746

149 Berven G, Saetre F, Halvorsen K, Seglen PO. Effects of the diarrhetic shellfish toxin, okadaic acid, on cytoskeletal elements, viability and functionality of rat liver and intestinal cells. Toxicon 2001; 39: 349362

150 Gordon PB, Holen I, Seglen PO. Protection by naringin and some other flavonoids of hepatocytic autophagy and endocytosis against inhibition by okadaic acid. J Biol Chem 1995; 270: 5830-5838

151 Møller MT, Samari HR, Fengsrud M, Strømhaug PE, øStvold AC, Seglen $P O$. Okadaic acid-induced, naringin-sensitive phosphorylation of glycine N-methyltransferase in isolated rat hepatocytes. Biochem J 2003; 373: 505-513

152 Larsen AK, Møller MT, Blankson H, Samari HR, Holden L, Seglen PO. Naringin-sensitive phosphorylation of plectin, a cytoskeletal cross-linking protein, in isolated rat hepatocytes. J Biol Chem 2002; 277: 34826-34835

153 Seo HJ, Jeong KS, Lee MK, Park YB, Jung UJ, Kim HJ, Choi MS. Role of naringin supplement in regulation of lipid and ethanol metabolism in rats. Life Sci 2003; 73: 933-946

154 Oliva J, French BA, Li J, Bardag-Gorce F, Fu P, French SW. Sirt1 is involved in energy metabolism: the role of chronic ethanol feeding and resveratrol. Exp Mol Pathol 2008; 85: 155-159

155 So FV, Guthrie N, Chambers AF, Moussa M, Carroll KK. Inhibition of human breast cancer cell proliferation and delay of mammary tumorigenesis by flavonoids and citrus juices. Nutr Cancer 1996; 26: 167181

156 Froufe HJ, Abreu RM, Ferreira IC. Using molecular docking to investigate the anti-breast cancer activity of low molecular weight compounds present on wild mushrooms. SAR QSAR Environ Res 2011; 22: $315-328$

157 Guo D, Wang J, Wang X, Luo H, Zhang H, Cao D, Chen L, Huang N. Double directional adjusting estrogenic effect of naringin from Rhizoma drynariae (Gusuibu). J Ethnopharmacol 2011; 138: 451-457

158 Schindler R, Mentlein R. Flavonoids and vitamin E reduce the release of the angiogenic peptide vascular endothelial growth factor from human tumor cells. J Nutr 2006; 136: 1477-1482

159 Fenton JI, Hord NG. Flavonoids promote cell migration in nontumorigenic colon epithelial cells differing in Apc genotype: implications of matrix metalloproteinase activity. Nutr Cancer 2004; 48: 182-188

160 Vanamala J, Leonardi T, Patil BS, Taddeo SS, Murphy ME, Pike LM, Chapkin RS, Lupton JR, Turner ND. Suppression of colon carcinogenesis by bioactive compounds in grapefruit. Carcinogenesis 2006; 27: 12571265

161 Sequetto PL, Oliveira TT, Maldonado IR, Augusto LE, Mello VJ, Pizziolo $V R$, Almeida MR, Silva ME, Novaes RD. Naringin accelerates the regression of pre-neoplastic lesions and the colorectal structural reorganization in a murine model of chemical carcinogenesis. Food Chem Toxicol 2014; 64: 200-209

162 Ramesh E, Alshatwi AA. Naringin induces death receptor and mitochondria-mediated apoptosis in human cervical cancer ( $\mathrm{SiHa}$ ) cells. Food Chem Toxicol 2013; 51: 97-105

163 Kim DI, Lee SJ, Lee SB, Park K, Kim WJ, Moon SK. Requirement for Ras/ Raf/ERK pathway in naringin-induced G1-cell-cycle arrest via p21WAF1 expression. Carcinogenesis 2008; 29: 1701-1709

164 Yeh SL, Wang WY, Huang CS, Hu ML. Flavonoids suppresses the enhancing effect of beta-carotene on DNA damage induced by 4-(methylnitrosamino)-1-(3-pyridyl)-1-butanone (NNK) in A549 cells. Chem Biol Interact 2006; 160: 175-182

165 Nie YC, Wu H, Li PB, Xie LM, Luo YL, Shen JG, Su WW. Naringin attenuates EGF-induced MUC5AC secretion in A549 cells by suppressing the cooperative activities of MAPKs-AP-1 and IKKs-IkB-NF- $k$ B signaling pathways. Eur J Pharmacol 2012; 690: 207-213

166 Prabu T, Ragunath M, Manju V. Antioxidant potential of naringin - a dietary flavonoid - in N-nitrosodiethylamine induced rat liver carcinogenesis. Biomed Prev Nutr 2012; 2: 193-202

167 Miller EG, Peacock JJ, Bourland TC, Taylor SE, Wright JM, Patil BS, Miller $E G$. Inhibition of oral carcinogenesis by citrus flavonoids. Nutr Cancer 2008; 60: 69-74

168 Greinert R, Volkmer B, Henning S, Breitbart EW, Greulich KO, Cardoso $M C$, Rapp A. UVA-induced DNA double-strand breaks result from the repair of clustered oxidative DNA damages. Nucleic Acids Res 2012; 40: 10 263-10 273
169 Kanno S, Tomizawa A, Hiura T, Osanai Y, Shouji A, Ujibe M, Ohtake T, Kimura K, Ishikawa $M$. Inhibitory effects of naringenin on tumor growth in human cancer cell lines and sarcoma S-180-implanted mice. Biol Pharm Bull 2005; 28: 527-530

170 Camargo CA, Gomes-Marcondes MC, Wutzki NC, Aoyama H. Naringin inhibits tumor growth and reduces interleukin- 6 and tumor necrosis factor $\alpha$ levels in rats with Walker 256 carcinosarcoma. Anticancer Res 2012; 32: 129-133

171 Oršolić N, Benković V, Lisičić D, Dikić D, Erhardt J, Knežević AH. Protective effects of propolis and related polyphenolic/flavonoid compounds against toxicity induced by irinotecan. Med Oncol 2010; 27: 1346-1358

172 Knežević AH, Dikić D, Lisičić D, Kopjar N, Oršolić N, Karabeg S, Benković $V$. Synergistic effects of irinotecan and flavonoids on Ehrlich ascites tumour-bearing mice. Basic Clin Pharmacol Toxicol 2011; 109: $343-$ 349

173 Pang WY, Wang XL, Mok SK, Lai WP, Chow HK, Leung PC, Yao XS, Wong MS. Naringin improves bone properties in ovariectomized mice and exerts oestrogen-like activities in rat osteoblast-like (UMR-106) cells. Br J Pharmacol 2010; 159: 1693-1703

174 Wong RW, Rabie AB. Effect of naringin on bone cells. J Orthop Res 2006; 24: 2045-2050

175 Wu JB, Fong YC, Tsai HY, Chen YF, Tsuzuki M, Tang CH. Naringin-induced bone morphogenetic protein-2 expression via PI3K, Akt, cFos/c-Jun and AP-1 pathway in osteoblasts. Eur J Pharmacol 2008; 588: 333-341

176 Li L, Zeng Z, Cai G. Comparison of neoeriocitrin and naringin on proliferation and osteogenic differentiation in MC3 T3-E1. Phytomedicine 2011; 18: 985-989

177 Ding $P$, Tang $Q$ Chen $L$. Effects of naringin on proliferation, differentiation and matrix mineralization of MC3 T3-E1 cells. Zhongguo Zhong Yao Za Zhi 2009; 34: 1712-1716

178 Zhang P, Dai KR, Yan SG, Yan WQ, Zhang C, Chen DQ Xu B, Xu ZW. Effects of naringin on the proliferation and osteogenic differentiation of human bone mesenchymal stem cell. Eur J Pharmacol 2009; 607: $1-5$

179 Wong RW, Rabie AB. Effect of naringin collagen graft on bone formation. Biomaterials 2006; 27: 1824-1831

180 Mandadi K, Ramirez M, Jayaprakasha GK, Faraji B, Lihono M, Deyhim F Patil BS. Citrus bioactive compounds improve bone quality and plasma antioxidant activity in orchidectomized rats. Phytomedicine 2009; 16: 513-520

181 Zhou X, Zhang P, Zhang C, Zhu Z. Promotion of bone formation by naringin in a titanium particle-induced diabetic murine calvarial osteolysis model. J Orthop Res 2010; 28: 451-456

182 Habauzit V, Sacco SM, Gil-Izquierdo A, Trzeciakiewicz A, Morand C, Barron D, Pinaud S, Offord E, Horcajada MN. Differential effects of two citrus flavanones on bone quality in senescent male rats in relation to their bioavailability and metabolism. Bone 2011; 49: 1108-1116

183 Chen LL, Lei LH, Ding PH, Tang $Q$ Wu YM. Osteogenic effect of Drynariae rhizoma extracts and Naringin on MC3 T3-E1 cells and an induced rat alveolar bone resorption model. Arch Oral Biol 2011; 56: $1655-1662$

184 Yu X, Zhao X, Wu T, Zhou Z, Gao Y, Wang X, Zhang CQ. Inhibiting wear particles-induced osteolysis with naringin. Int Orthop 2013; 37: 137143

185 Ang ES, Yang X, Chen H, Liu Q Zheng MH, Xu J. Naringin abrogates osteoclastogenesis and bone resorption via the inhibition of RANKL-induced NF- $k$ B and ERK activation. FEBS Lett 2011; 585: 2755-2762

186 Wei M, Yang Z, Li P, Zhang Y, Sse WC. Anti-osteoporosis activity of naringin in the retinoic acid-induced osteoporosis model. Am J Chin Med 2007; 35: 663-667

187 Kawaguchi K, Maruyama H, Hasunuma R, Kumazawa Y. Suppression of inflammatory responses after onset of collagen-induced arthritis in mice by oral administration of the Citrus flavanone naringin. Immunopharmacol Immunotoxicol 2011; 33: 723-729

188 Nowak-Solinska E, Rabie AB, Wong RW, Lei SW. The effect of naringin on early growth and development of the spheno-occipital synchondrosis as measured by the expression of PTHrP and Sox9 - an in vitro model. Eur J Orthod 2013; 35: 826-831

189 Li A, Zhao JJ, Liu J, Shi JF, Rao GZ, Wei H, Gou JZ. Experimental study on the functional regulation of naringin in human periodontal ligament cells. Shanghai Kou Qiang Yi Xue 2011; 20: 561-566 
190 Tsui VW, Wong RW, Rabie AB. The inhibitory effects of naringin on the growth of periodontal pathogens in vitro. Phytother Res 2008; 22: 401-406

191 Wood N. The effects of dietary bioflavonoid (rutin, quercetin, and naringin) supplementation on physiological changes in molar crestal alveolar bone-cemento-enamel junction distance in young rats. J Med Food 2004; 7: 192-196

192 Wood $N$. The effects of selected dietary bioflavonoid supplementation on dental caries in young rats fed a high-sucrose diet. J Med Food 2007; 10: 694-701

193 Itoh K, Hirata N, Masuda M, Naruto S, Murata K, Wakabayashi K, Matsuda $H$. Inhibitory effects of Citrus hassaku extract and its flavanone glycosides on melanogenesis. Biol Pharm Bull 2009; 32: 410-415

194 Itoh K, Masuda M, Naruto S, Murata K, Matsuda H. Anti-allergic activity of unripe Citrus hassaku fruits extract and its flavanone glycosides on chemical substance-induced dermatitis in mice. J Nat Med 2009; 63: $443-450$

195 Gao S, Li P, Yang H, Fang S, Su W. Antitussive effect of naringin on experimentally induced cough in Guinea pigs. Planta Med 2011; 77: 16 21

196 Kawaguchi K, Kikuchi S, Hasunuma R, Maruyama H, Ryll R, Kumazawa $Y$. Suppression of infection-induced endotoxin shock in mice by a citrus flavanone naringin. Planta Med 2004; 70: 17-22

197 Lakshmi V, Joseph SK, Srivastava S, Verma SK, Sahoo MK, Dube V, Mishra SK, Murthy PK. Antifilarial activity in vitro and in vivo of some flavonoids tested against Brugia malayi. Acta Trop 2010; 116: 127-133

198 Zandi K, Teoh BT, Sam SS, Wong PF, Mustafa MR, Abubakar S. Antiviral activity of four types of bioflavonoid against dengue virus type-2. Virol J 2011; 8: 560
199 Duda-Chodak A. The inhibitory effect of polyphenols on human gut microbiota. J Physiol Pharmacol 2012; 63: 497-503

200 Céliz G, Daz M, Audisio MC. Antibacterial activity of naringin derivatives against pathogenic strains. J Appl Microbiol 2011; 111: 731-738

201 Lambev I, Belcheva A, Zhelyazkov D. Flavonoids with antioxidant action (naringin and rutin) and the release of mastocytic and nonmastocytic histamine. Acta Physiol Pharmacol Bulg 1980; 6: 70-75

202 Oh HA, Kim MJ, Shin TY, Kim HM, Jeong HJ. The antiallergic mechanisms of Citrus sunki and bamboo salt (K-ALL) in an allergic rhinitis model. Exp Biol Med (Maywood) 2014; 239: 83-93

203 Galati EM, Monforte MT, d'Aquino A, Miceli N, Di Mauro D, Sanogo R. Effects of naringin on experimental ulcer in rats. Phytomedicine 1998; 5: 361-366

204 Martín MJ, Marhuenda E, Pérez-Guerrero C, Franco JM. Antiulcer effect of naringin on gastric lesions induced by ethanol in rats. Pharmacology 1994; 49: 144-150

205 Jang Y, Kim TK, Shim WS. Naringin exhibits in vivo prokinetic activity via activation of ghrelin receptor in gastrointestinal motility dysfunction rats. Pharmacology 2013; 92: 191-197

206 Oki K, Plonczynski MW, Lam ML, Gomez-Sanchez EP, Gomez-Sanchez $C E$. The potassium channel, Kir3.4 participates in angiotensin II-stimulated aldosterone production by a human adrenocortical cell line. Endocrinology 2012; 153: 4328-4335

207 Herrera MD, Marhuenda E. Effect of naringin and naringenin on contractions induced by noradrenaline in rat vas deferens-I. Evidence for postsynaptic alpha-2 adrenergic receptor. Gen Pharmacol 1993; 24: 739-742

208 Shaik $N$, Zbidah $M$, Lang $F$. Inhibition of $\mathrm{Ca}(2+)$ entry and suicidal erythrocyte death by naringin. Cell Physiol Biochem 2012; 30: 678686 